\title{
Origin of salinity in a multilayered aquifer with high salinization vulnerability
}

\author{
Nathalie Gassama ${ }^{1 *}$, Aline Dia ${ }^{2}$ and Sophie Violette ${ }^{3}$
}

1: Université François Rabelais-Tours, INSU/CNRS, Université d’Orléans, Institut des Sciences de la Terre d’Orléans - ISTO UMR 6113, UFR des Sciences et Techniques, Parc de Grandmont, 37200 Tours, France. Tel: 332473671 18; fax: 33247367090. nathalie.gassama@univ-tours.fr

2: CNRS-UMR 6118-Géosciences Rennes, Université de Rennes, Campus Beaulieu, av. du Général Leclerc, 35042 Rennes cedex, France. aline.dia@univ-rennes1.fr

3: CNRS-UMR 7619-Sisyphe, Laboratoire de Géologie Appliquée, Université Pierre et Marie Curie, case 123, 4 place Jussieu, 75252 Paris cedex 05, France. sophie.violette@upmc.fr

\section{Abstract}

The Kaluvelly watershed is a coastal area (Tamil Nadu, India) where water abstraction has resulted in a dramatic fall in the level of the water table and a piezometric depression in the most exploited aquifer, the Vanur aquifer. In addition, intensification/mechanization of agriculture may have affected the quality of recharge water. An initial hydrodynamic study showed that the Vanur aquifer is highly vulnerable to salinization due to potential seawater intrusion, and our aim was to determine the source of salinity recorded in the groundwater of this multilayered aquifer. Our approach involved the use of existing boreholes and of a moderate number of samples, with the aim of developing appropriate water resource management techniques. Major elements, ${ }^{18} \mathrm{O} /{ }^{16} \mathrm{O},{ }^{2} \mathrm{H} /{ }^{1} \mathrm{H}$, and ${ }^{87} \mathrm{Sr} /{ }^{86} \mathrm{Sr}$ ratios were measured in rainwater, surface water and groundwater collected during five sampling campaigns over a two-year period. Geochemical data indicate that the Vanur aquifer is recharged and that small mixings between aquifers fluctuate according to monsoon intensity. There was no evidence of seawater intrusion. The range of recorded salinity originated mainly from water-rock interaction but a disconnection of some deeper parts of the aquifer was apparent. Strontium isotopic ratios in the recharge area suggest an anthropogenic influence, possibly related to fertilizer use. A high $\mathrm{SO}_{4} / \mathrm{Cl}$ ratio was observed in the aquifer; in the deeper parts, the influence of a formation containing lignite is hypothesized, whereas near the surface, sulphate may partly originate from fertilizer use and fossil fuel combustion. Water isotopic data

\footnotetext{
* corresponding author: nathalie.gassama@univ-tours.fr; fax: 33247367090
}

This article has been accepted for publication and undergone full scientific peer review but has not been through the copyediting, typesetting, pagination and proofreading process which may lead to differences between this version and the Version of Record. Please cite this article as an 'Accepted Article', doi: 10.1002/hyp.8125 
suggest that the origin of precipitation in this region has been unchanged for several hundreds or thousands of years.

KEY WORDS: salinization, groundwater, geochemistry, $\mathrm{O}, \mathrm{H}$ and $\mathrm{Sr}$ isotopes.

\section{INTRODUCTION}

Increased salinity of groundwater is a widespread problem and insight into the underlying processes is of strategic water resource importance (Edmunds, 2003). Predicting trends in salinity patterns can enhance the efficiency of groundwater exploration and help choosing the most appropriate groundwater management policies (Darwish et al., 2005; Sheng and Xiuling, 2007; Khan and Hanjra, 2008; Petheram et al., 2008).

There are a great number of papers dealing with groundwater salinization processes in both coastal and non-coastal areas, but they have produced conflicting conclusions regarding the origin of increased salinity. A wide range of processes has been suggested. Salinization can result from one main process or source, for example, seawater intrusion due to over-pumping (Kim et al., 2003; Capaccioni et al. 2005) generally accompanied by a cationic exchange on clays (Pulido-Leboeuf, 2004), intrusion of modern marine-estuarine and confined paleomarine water (Sukhija et al., 1996), dissolution and infiltration of evaporites from sand dune deposits in coastal areas (Yoon, 1986), upwelling of deep saline waters (Naftz et al., 1997; Vengosh et al., 1999), past or current intense evaporation (Sukhija et al., 1998; Herczeg et al., 2001), past and current water intrusion from a saline river in arid areas (Faye et al., 2005), etc. In many cases, salinization is the result of several combined processes, such as seawater intrusion with the input of deep mineralized water (Morell et al., 1996; Shavit and Furman, 2001; Sanchez Martos et al., 2002) and agricultural practices (Stigter et al., 1998) or fertilizer uses (Oren et al., 2004), or seawater intrusion coupled with sewage discharge in rivers and water-rock interaction (Park et al., 2005). The source of salinization can be difficult to identify, because many different processes can produce a chemical signature of groundwater similar to that of seawater. All the here above mentioned studies were based on large data bases involving considerable costs for monitoring and analysis, and sometimes requiring the drilling of new boreholes. Our objective was to describe water mixing using existing boreholes and a few geochemical tools with a moderate number of samples. 
In the Kaluvelly watershed (Figure 1) (Tamil Nadu, India), traditional agricultural practices were based on collecting rainfall in shallow tanks (called "erys" in Tamil). Since the 1970s, as the groundwater resource appeared more reliable and productive than rainfall harvesting, more than a thousand boreholes have been drilled in the sedimentary part, which forms a multilayered aquifer (Figure 2), mainly tapping the Vanur sandstone aquifer. Since 1991, the Auroville Water Service (AWS), a non-governmental organization concerned with water management in this part of the watershed, has monitored water level and quality at several boreholes in the Vanur village region (Pougajendy et al., 1997a and 1997b; Gablier et al., 2000). A dramatic fall in the level of the water table was recorded between 1975 and 2001 in the Vanur sandstone aquifer; in the Vanur village, the piezometric level fell from about $7 \mathrm{~m}$ a.m.s.l. (above mean sea level) in 1975 (Krupanidhi et al., 1979) to a minimum of $-35 \mathrm{~m}$ a.m.s.l. in June 2001 (AWS, this study, Figure 3). Proximity to the sea raises the risk of seawater flowing into the Vanur aquifer. In addition, the Kaluvelly swamp (Figure 1), at the end of the surface drainage area in the north of the catchment, is replenished with brackish water. Several sources of salinization may be involved, since north and south parts of the Kaluvelly catchment are surrounded by solute-enriched groundwater (Natarajan et al., 2003). Intensification of agriculture (increased irrigation and use of fertilizers and pesticides) might also affect the water quality of the aquifers through recharge with irrigation waters enriched in nutrients, pesticides and accompanying solutes such as chloride, fluoride, arsenic, etc.

This study combined hydrological, hydrogeological and geochemical tools with the aim of identifying the key factors governing the water chemical composition. For the geochemical study, major- and trace-element concentrations, and ${ }^{18} \mathrm{O} /{ }^{16} \mathrm{O},{ }^{2} \mathrm{H} /{ }^{1} \mathrm{H}$, and ${ }^{87} \mathrm{Sr} /{ }^{86} \mathrm{Sr}$ ratios were measured in rainwater, surface water and groundwater collected during five sampling campaigns carried out between 1999 and 2001. Data from the two first surveys (January 1999 and October 2000) evidenced water circulation and were used to construct a $1 \mathrm{D}$ hydrodynamic model (D’Ozouville et al., 2006). Hydrodynamic calculations showed that seawater intrusion was expected to occur 3 to 20 years after 2000 (according to available hydrogeological parameters). Geochemical data indicate that salinity in the Vanur aquifer cannot be due to simple seawater intrusion. The entire dataset was used to determine more precisely the hydraulic connections between aquifers and the hydrodynamic circulation within each of the most exploited aquifers (the charnockites, the Vanur and the Cuddalore). In addition, evidence of the impact of fertilizer use and water-rock interaction was found in the geochemical signature (major element concentrations and ${ }^{87} \mathrm{Sr} /{ }^{86} \mathrm{Sr}$ ratios) of groundwater, as elsewhere in other contexts (Négrel and Deschamps, 1996; Négrel et al., 2000; 2003; Semhi 
et al., 2000; Ojiambo et al., 2003 and references therein). The aim of this study was to provide both a better understanding of the key mechanisms involved over time and essential information for developing effective water resource management strategies.

\section{GEOLOGICAL AND HYDROGEOLOGICAL BACKGROUND}

Rainfall records, piezometric and hydrogeological data were used to define the system, as described by d'Ozouville et al. (2006).

The Kaluvelly watershed consists of Archaean bedrock (charnockites) which outcrops on the western part (2/3 of the total area), overlain by Mesozoic and Cenozoic sedimentary beds. These beds consist of alternating sandstone and clays derived from the erosion of the bedrock and biogenic limestone (Figure 2), forming a multilayered aquifer. The sedimentary beds dip and thicken seaward, reaching a depth of up to $550 \mathrm{~m}$ at the coast. The Kaluvelly swamp, at the end of the surface drainage area, lies on the alluvial deposits, which cover the NorthEastern part of the watershed. A sluice gate has been built at the end of the swamp to prevent any connection with the sea. However, due to lack of maintenance, seawater occasionally enters and freshwater runs out of the swamp. The sedimentary landscape is very flat with some charnockite inselbergs.

The three main aquifers used are, from the bottom to the top of the stratigraphic sequence:

(i) the discontinuous charnockite aquifer, mainly tapped at the outcrop;

(ii) the Vanur sandstone aquifer, which outcrops to the west and becomes confined under the Ottai clays towards the east (seaward);

(iii) the Cuddalore sandstone aquifer, the top formation occurring as small plateaus in the eastern and western parts of the sedimentary basin.

Four other formations of interest are, from bottom to top: Ramanathapuram sandstone (with lignite beds) occurring with variable thickness above the charnockite bedrock and below the Vanur aquifer, Ottai clays which contain water-bearing limestone lenses and are located just above the Vanur aquifer, Turuvai limestone, and Kadaperikuppam sandstone. Superficial aquifers in the alluvium deposits and dunes were not included in this study because they do not contribute to the water budget of the Kaluvelly watershed (Jaya Kumar et al., 1984).

Reddy and Rao (1997) showed that Holocene deposition on the Pleistocene erosional surface in the non-deltaic off-shore area consists of mud, muddy sand and sand. The Pleistocene erosion surface has a varying relief with a thickness of 2 to $8 \mathrm{~m}$ at depths of 53 to 
$90 \mathrm{~m}$. If the off-shore sedimentary beds continue to dip seaward, the hydraulic connection between the aquifers and the ocean should be very low. Without any output to the sea, infiltration waters must have been stored and accumulated for several hundreds or thousands of years, representing a considerable amount of water.

The Kaluvelly watershed has a tropical semi-arid climate with a mean annual rainfall of 1,290 +/- 381 mm (Pondicherry meteorological station, 1911-1971/1984-1995 and Auroville station 1972-1983/1996-2001, see d’Ozouville et al. (2006) for further details) mainly brought by the NE monsoon (October to December). The aquifer is replenished during this period.

These data indicate that the Vanur aquifer is replenished at the outcrop through rainfall, erys and irrigation, and a large amount of water is likely to have been stored in its deeper parts for hundreds or thousands of years. Four of the studied boreholes have been regularly monitored by the AWS in Auroville: two in the Vanur sandstone aquifer (Auroshilpam „\#47, and Aurogreen, \#48), and two in the Cuddalore sandstone aquifer (Utility, \#38, and Auromodele, \#39) (Table 1). During the rainfall-deficient period of 1995 to 1998, increased conductivity was recorded in these two aquifers (AWS data). Although there was no shortage of rain during the study period (1999-2001), conductivity increased slightly in \#47 and \#48 (Vanur), but not in \#38 and \#39 (Cuddalore). During the same period, we measured a wide range of total dissolved solids (TDS) in both aquifers.

\section{SAMPLING AND ANALYTICAL PROCEDURE}

\section{Sampling}

The wells and boreholes used for sampling are mainly located in the three main aquifers: nine in Cuddalore, sixteen in Vanur, eight in the charnockite one. Some samples were taken from the intermediate aquifers: three from Kadaperikuppam, one from Turuvai, and two from the Ottai formation (Table 1). Surface water was also sampled at nine erys and swamp sites. Rainfall was collected whenever possible. The first samples were collected in January 1999, followed by four collections during a single hydrological year (October 2000 - October 2001), before and after two monsoon seasons: January 1999 (HA series), October 2000 (HB series), January 2001 (HC series), June 2001 (HD series) and October 2001 (HE series).

The boreholes used for monitoring had been drilled for agricultural or domestic purposes. Priority was given to cased boreholes. However, since most existing boreholes were not cased, there was always the danger that deep water samples were a mixing of waters from 
different aquifers. Therefore, the charnockite waters were sampled only at the outcrop, mainly from "dug-cum-boreholes", former open wells that had been drilled following the water level drop. Samples from the Vanur aquifer were taken from both the confined and unconfined areas. Apart from \#23 and \#28 which are equipped with hand pumps, all the boreholes have diesel pumps, and water was sampled after at least ten minutes of pumping (stable temperature) to prevent any contamination.

Some fertilizers commonly used in the area were also sampled (Auroville Water Service, 2000) in order to estimate their impact on the chemical composition of infiltration water.

Samples for chemical and ${ }^{87} \mathrm{Sr} /{ }^{86} \mathrm{Sr}$ analysis were filtered on site on $0.45 \mu \mathrm{m}$ and $0.1 \mu \mathrm{m}$ cellulose acetate membranes respectively, previously rinsed with the sample. Aliquots for analysis of cations, nutrients and $\mathrm{Sr}$ were acidified to $\mathrm{pH}=2$ with Suprapur@ grade nitric acid. Samples were then UV-irradiated for 3 hours to stop any biological activity and then stored at about $4^{\circ} \mathrm{C}$ in polypropylene bottles until the day of analysis. Unfiltered and non-acidified samples were collected specifically for $\delta^{18} \mathrm{O}$ and $\delta \mathrm{D}$ determinations and stored in zero headspace amber glass bottles.

\section{Analytical methods}

Electric conductivity, $\mathrm{pH}$ and temperature were measured in the field. Alkalinity was measured by titrimetry (Gran method calculation) on the sampling day. Major cation (Na, K, $\mathrm{Ca}, \mathrm{Mg}$ ) concentrations were determined by atomic absorption or emission flame spectrometry (uncertainties of \pm 2 to $4 \cdot 10^{-6} \mathrm{~mol} / \mathrm{L}$ ), and anion $\left(\mathrm{Cl}^{-}, \mathrm{SO}_{4}{ }^{2-}, \mathrm{NO}_{3}{ }^{-}\right)$ concentrations were measured by ionic chromatography (uncertainties: $\mathrm{Cl}^{-} \pm 2 \cdot 10^{-5} \mathrm{~mol} / \mathrm{L}$; $\left.\mathrm{SO}_{4}{ }^{2-} \pm 5 \cdot 10^{-6} \mathrm{~mol} / \mathrm{L} ; \mathrm{NO}_{3}{ }^{-} \pm 2 \cdot 10^{-7} \mathrm{~mol} / \mathrm{L}\right)$. Colorimetry was used to measure $\mathrm{H}_{4} \mathrm{SiO}_{4}\left( \pm 2 \cdot 10^{-}\right.$ $\left.{ }^{5} \mathrm{~mol} / \mathrm{L}\right)$ and $\Sigma \mathrm{PO}_{4}\left( \pm 3 \cdot 10^{-7} \mathrm{~mol} / \mathrm{L}\right)$.

The conventional chromatographic method was used to separate Sr using Sr-Spec Eichrom (Pin et al., 1994) and a combination of $\mathrm{HNO}_{3}$ and $\mathrm{H}_{2} \mathrm{O}$. Total blanks for Sr were less than 60 pg and were negligible compared to the amounts of Sr in the samples. The Sr concentrations were determined by Inductively Coupled Plasma Mass Spectrometry (HP 4500) (detection limit: 2 ppt and precision $\pm 2 \%$ ). Strontium isotopic analyses were performed by thermal ionization mass spectrometry using a Finnigan ${ }^{\circledR}$ MAT 262 multicollector mass spectrometer. During the course of this study, the NBS $987 \mathrm{Sr}$ standard yielded a mean ${ }^{87} \mathrm{Sr} /{ }^{86} \mathrm{Sr}$ ratio of $0.710245 \pm 13$. 
The $\delta^{18} \mathrm{O}$ analyses of the $\mathrm{HA}$ series waters were performed by $\mathrm{CO}_{2}$ equilibration followed by CF-IRMS measurements on a minimum of three replicates $(1 \sigma=0.15 \%$ o with respect to SMOW) (Laboratoire de Géochimie des Isotopes Stables, IPGP, France). The $\delta \mathrm{D}$ determinations for the HA series $(1 \sigma=0.8 \%$ with respect to SMOW) were performed by water- $\mathrm{H}_{2}$ equilibration catalyzed with small Pt-coated balls (diameter $1 \mathrm{~mm}$ ) called "Hokko beads”, as described by Horita et al. (1989) (Bureau de Recherches Géologiques et Minières (BRGM), Orléans, France). The $\delta \mathrm{D}$ and $\delta^{18} \mathrm{O}$ determinations for the $\mathrm{HB}$ and $\mathrm{HC}$ series $(1 \sigma=$ $1 \%$ and $1 \sigma=0.1 \%$ with respect to SMOW, respectively) were carried out as described by Coleman et al. (1982) and Epstein and Mayeda (1953) (ISO4, University of Turin, Italy).

The chemical and isotopic analyses of solid fertilizers were performed using the same analytical methods as here above described, after dissolution in de-ionized then filtered water.

\section{RESULTS}

In ery, well and borehole waters, the dominant water types were Ca- or $\mathrm{Na}-\mathrm{HCO}_{3}$, and $\mathrm{Na}$ $\mathrm{Cl}$ for some charnockite waters (d'Ozouville et al. (2006) for HA and HB series, Table 2 for $\mathrm{HC}$ to $\mathrm{HE}$ series). Waters were both silicium- and hydrogenocarbonate-rich. The high $\mathrm{HCO}_{3}{ }^{-}$ concentrations measured in these waters, which drain predominantly silicate terrains, may seem surprising. However, during silicate mineral weathering, cations are mainly released, and an increase in $\mathrm{CO}_{2}$ dissolution is observed to form $\mathrm{HCO}_{3}{ }^{-} / \mathrm{CO}_{3}{ }^{2-}$ to balance the cation charge. $\mathrm{CO}_{2}$ is provided partly by the atmosphere but also mainly by the rapid decomposition of organic matter in tropical soils. Accordingly, the samples presenting the highest contents of carbonate species were those taken from the superficial aquifer of Cuddalore (short residence time and proximity to organic matter-rich horizons). The range of Total Dissolved Solids (TDS) for the whole series was as follows: 200 to $500 \mathrm{mg} / \mathrm{L}$ in the Cuddalore, with the exception of HE53 (700 mg/L); 600 to 1,400 mg/L in the Vanur; 500 to 1,700 mg/L in charnockite with the exception of HA23 (2,300 mg/L); in other aquifers, it ranged from 400 reaching 5,000 $\mathrm{mg} / \mathrm{L}$ in the Ottai (HC28).

For the saturation index, the Davies equation was used to calculate the activity coefficient, with thermodynamic data from WATEQ4F (Ball and Nordstrom, 1991), assuming that reactions occurred at $25^{\circ} \mathrm{C}$ and $1 \mathrm{~atm}$. We tested a carbonate phase (calcite) and four sulphate phases (gypsum, anhydrite, thenardite and mirabilite). Results are here below presented. 


\section{Surface water: ery, rainwater, swamp}

Erys were only sampled in January 1999 and 2001, after the monsoon. Because of the low relief, erys act as pluviometers, apart from the one at Nesal which is partly supplied by running water. Calculated TDS ranged from 55 to $240 \mathrm{mg} / \mathrm{L}$ in January 1999, and from 70 to $310 \mathrm{mg} / \mathrm{L}$ in January 2001 (Table 2). The replenishment and chemistry of the erys show that the 1998-1999 winter monsoon was more severe than the one of winter 2000-2001 (when only three of the six erys contained water). Ery waters are used for both irrigation and domestic purposes (washing and occasionally bathing). The impact of domestic uses can be observed from the $\mathrm{Na}^{+}$and $\mathrm{SO}_{4}{ }^{2-}$ content and $\mathrm{pH}$ (from soap), mainly for \#8, when comparing the January 1999 and 2001 results.

Because only small quantities of rainwater could be collected, samples were mainly used to characterize the meteoric water isotope ratio of this area. Mean ery water chemistry (MEW), calculated from January 1999 data, was used to define the chemical composition of the water entering the aquifers, i.e. rainwater which had only slightly reacted with soils and which had evaporated either slightly or not at all (Table 2). Average seawater composition (ASW) was calculated to test any mixing with seawater, using data presented in Berner and Berner (1996).

Swamp waters are brackish and their salinity depends on rainfall, sea connection and evaporation. Because of the flat topography, there is considerable seasonal variation in the water replenishment of the swamp. During the dry season, two thirds of the swamp area are dry, only the north-east part being permanently waterlogged. Dried land is used for agriculture. We monitored two sites in the swamp: an inner site (\#20) and a second site at the sluice gate (\#22). After a period of more or less intense rainfall (January 1999 and January 2001 respectively), the chemistry of the swamp waters indicates a mixing of surface waters (MEW) and seawater as assessed by $\mathrm{Na}, \mathrm{Ca}, \mathrm{Cl}$ and $\mathrm{SO}_{4}$ (Figures $4 \mathrm{a} \& \mathrm{~b}$ ). During the dry season, sulphate depletion was observed (Figure 4b); calculation of saturation indexes shows that this could not be due to a sulphate phase precipitation (gypsum, anhydrite, thenardite, mirabilite), and it is likely that the trophic condition of the swamp (probably eutrophic, personal observation) led to part of the sulphate ions being reduced and released as sulphide during the biological oxidation of organic matter. This hypothesis is corroborated by the low concentrations of nitrate (Table 2) as compared to those sampled in surface water. The solution is close to equilibrium toward calcite in HA22 and HC22, and over-saturated in HA20 and HD22. 
The chemical characteristics of the swamp waters indicate a large input of surface/running water in January 1999, evaporation in October 2000 and June 2001, and confirm that the 2000-2001 winter monsoon was rather weak.

\section{Groundwaters from the three main aquifers}

The Cuddalore is an unconfined aquifer. In the Vanur aquifer, \#15, \#16, \#17 and \#25 are in the unconfined area and the other boreholes in the confined area. The charnockite boreholes are located in the outcrop area.

Calculation of saturation indexes shows that Cuddalore waters were undersaturated with respect to calcite. Some Vanur (HB7, HC7, HE15, HE16, HE26) and charnockite waters (\#2, \#32, HC34, HC50, HC52, HD52, HE34) were in equilibrium with calcite.

The chemical composition of waters from the Cuddalore showed seasonal variations, with lower salinity after the monsoon in January and an increase in TDS from June to October (Table 2). In the Vanur aquifer, this seasonal pattern was less pronounced and occurred later due to water travel time. This may explain the slight increase in conductivity recorded in \#47 and \#48 from 1999 to 2001, while the rainfall-deficient period was between 1995 and 1998. By contrast, no seasonal variation was observed in the charnockite aquifer water which had high salinity varying significantly between boreholes and across time for individual boreholes. Charnockite waters exhibited the same general chemical characteristics as Cuddalore and Vanur waters, linked to similar geochemistry of host-rocks, the Vanur and Cuddalore sandstones being composed of charnockite-sourced detritic deposits. However, the waters from these three aquifers cannot be differentiated with binary diagrams plotting concentrations of major elements, such as $\mathrm{Na}^{+}$versus $\mathrm{Cl}^{-}$(Figure 5a).

Cuddalore. The chemical composition of the water from the Cuddalore aquifer shows a limited range. This water is characterized by low TDS and low Mg concentrations (Table 2). Among all major element ratios, the distribution of $\mathrm{Ca} / \mathrm{Mg}$ ratios as a function of $\mathrm{Mg} / \mathrm{K}$ ratios (Figure 6) allows the identification of the Cuddalore waters as a distinct and homogeneous group, with an $\mathrm{Mg} / \mathrm{K}$ ratio ranging from 0 to 10 and a $\mathrm{Ca} / \mathrm{Mg}$ ratio ranging from 1.5 to 3.5 throughout the studied period. Water with the lowest salinity was located close to the top of the hill of Auroville, \#43, then \#39 and \#42, corresponding to the recharge waters of the Cuddalore aquifer. Input of recharge waters reduced the $\mathrm{Ca} / \mathrm{Mg}$ ratio (Figures $6 \mathrm{a}$ to $6 \mathrm{~d}$ ). The $\mathrm{SO}_{4} / \mathrm{Cl}$ ratio ranged from 0.05 to 0.15 (expressed as a molar ratio; October) (Figure 7). In one 
borehole (\#40), water was possibly mixed with irrigation waters with high chloride and nitrate contents (Figures $5 \mathrm{a}$ and $\mathrm{b}$ ). This chemical signature records amount, method and quality of fertilizer application, nitrogen uptake by crop and evaporation/evapotranspiration as well (Stigter et al., 2006).

Vanur. Water with the highest salinity was found in the deepest part of the confined area of the Vanur aquifer (\#29, \#35, \#47 and \#48) (Tables 1 and 2, Figure 5a), while the lowest salinity was measured in the unconfined area (\#15, \#16, \#17, \#25 and \#30). A chemical gradient was recorded from the recharge area to the deepest parts of the confined area (Figure 5a). Distribution of $\mathrm{Ca} / \mathrm{Mg}$ ratios as a function of $\mathrm{Mg} / \mathrm{K}$ ratios (Figure 6) showed a trend between two kinds of water, from \#48 and \#47 to \#30, with $\mathrm{Mg} / \mathrm{K}$ and $\mathrm{Ca} / \mathrm{Mg}$ ratios ranging from 10 to 30 and from 0.5 to 1.5, respectively. Samples from \#47 and \#48 were enriched in $\mathrm{Ca}$ and $\mathrm{K}$ as compared to other Vanur boreholes (Figure 6) and come within the Cuddalore domain. In October 2000, the water chemical composition in two boreholes (\#26 and \#35) differed from that found in samples from other boreholes (Figure 6a) and then tended to present the same $\mathrm{Ca} / \mathrm{Mg}$ and $\mathrm{Mg} / \mathrm{K}$ ratio from October 2000 to October 2001 (Figures 6 a to d). For \#35, an input of water similar to \#37 (Ottai aquifer) is hypothesized. The mean concentration of chloride recorded in boreholes from the recharge area suggests that \#16 could be contaminated by anthropogenic chloride (e.g. $\mathrm{KCl}$ ) (Figure 5a). Nitrate contents corroborate this hypothesis (Figure 5b). An input of irrigation waters is also suspected for \#35 (Figure $5 b$ ). In the Vanur aquifer, the $\mathrm{SO}_{4} / \mathrm{Cl}$ ratio increased with the salinity of water, from 0.05 to 0.65 (expressed as a molar ratio; October 2000) (Figure 7). The chemical composition of the Vanur waters varied from \#25 (unconfined area), which could represent the recharge waters, to an enriched end-member at \#29 (confined area, depth 200m) (Figure 5a).

Charnockite. Various chemical compositions were observed in the groundwater in the charnockite aquifer. No clear chemical pattern can be observed in binary diagrams (e.g. Figure 5a) and these waters presented extremely variable $\mathrm{Mg} / \mathrm{K}$ (from 0.4 to 110 ) and $\mathrm{Ca} / \mathrm{Mg}$ ratios (from 0.6 to 4.1) (Figure 6). Charnockite waters are mineralized, such as Vanur waters, but are sulphate-depleted (Figure 7). The $\mathrm{SO}_{4} / \mathrm{Cl}$ ratios ranged from 0.05 to 0.25 (expressed as a molar ratio) in October 2000. In several boreholes (\#23, \#31, \#32, \#33, \#50, \#52) an input of rich irrigation waters is suspected because of the high concentrations of both chloride and nitrate (Figure 5b). This is corroborated by high concentrations of orthophosphate (not presented in Table 2; between 5 and $7 \cdot 10^{-5} \mathrm{~mol} / \mathrm{L}$ ) recorded in \#23. Since the chemical 
signatures recorded in the different charnockite boreholes were similar, there is no evidence of hydraulic connection between them, which is in accordance with the aquifer characteristics (water circulation through fractures and alterite pockets).

To sum up, recharge was rapid in the Cuddalore with seasonal TDS variations, and recharge was delayed but steady in the Vanur (Table 2), while no regular pattern was observed in the charnockite. Cuddalore and Vanur waters form a homogeneous cluster, whereas charnockite waters represent a heterogeneous cluster. Cuddalore waters were less saline than Vanur and charnockite waters which exhibited the same salinity range. In the Vanur, \#47 and \#48 exhibited $\mathrm{Ca} / \mathrm{Mg}$ and $\mathrm{Mg} / \mathrm{K}$ ratios that differed widely from those found in samples taken from all the other deep boreholes in this aquifer, locating them in the Cuddalore domain. In the deepest part of the Vanur aquifer, waters exhibited unexpected heterogeneity as compared to other waters, particularly wells in the area with the lowest pressure (\# 13, 29, 35; Tables 1 and 2, Figures 1 and 3), and presented the largest time variation. This could indicate a poor connection of these wells with the rest of the aquifer, possibly linked to (i) a heterogeneous permeability of the aquifer, (ii) hydraulic connection with other aquifers (natural or through boreholes), or (iii) disconnection/isolation of some parts of the aquifer due to the balance between abstractions and recharge.

\section{Groundwater from the other aquifers}

Other aquifers, Kadaperikuppam (\#9, \#11, \#51), Ottai (\#28 and \#37) and Turuvai (\#36), were sampled in order to identify any connections. Apart from \#28 which had very high salinity, samples from all the boreholes had medium salinity values (Table 2). However, borehole \#28 is equipped with a hand pump and is exposed to village input.

Water sampled (at the outcrop) from the Kadaperikuppam aquifer (calcareous sandstone) was not Ca-rich, compared to water from the Vanur aquifer, but K-depleted. It was more enriched in chloride than did the Vanur recharge waters, and exhibited a very stable $\mathrm{SO}_{4} / \mathrm{Cl}$ ratio: 0.4 for \#9 and 0.1 for \#11. Samples from HA9, HA11, HB9, HC11, HD11, and HE9 were in equilibrium with calcite.

The two boreholes monitored in Ottai had very different chemical signatures. The data are in accordance with the geometry of this discontinuous aquifer (occurring as limestone lenses in clays). The chemical signature of these samples also differed from those in the other aquifers. Samples from \#28 exhibited high TDS (from 2700 to $5100 \mathrm{mg} / \mathrm{L}$ ), and were more enriched in $\mathrm{Na}, \mathrm{Mg}$ and chloride than samples from Vanur. Water from \#37 was more 
enriched in $\mathrm{Ca}$ and chloride, and more K-depleted than samples from Vanur. The $\mathrm{SO}_{4} / \mathrm{Cl}$ ratio calculated for both boreholes was very stable through time: about 0.3 and 0.7-0.9 for \#28 and \#37, respectively. Only HE37 was close to equilibrium with respect to calcite, whereas all the other samples taken from this borehole were under-saturated, similar to those taken from \#28.

The chemical signature of water from \#36 (Turuvai) was similar to that of Vanur samples. The $\mathrm{SO}_{4} / \mathrm{Cl}$ ratios ranged through time from 0.06 to 0.1 . Water from \#36 was undersaturated with respect to calcite, except in October 2001 (HE36) when it was close to equilibrium.

\section{Salinity time variation}

The salinity time-variation study focused on Vanur because it is the most tapped aquifer.

As the salinity variability recorded in this aquifer could be caused by seawater input, $\mathrm{Na}^{+}$, $\mathrm{Cl}^{-}, \mathrm{SO}_{4}{ }^{2-}$ and TDS data were used to identify the involved processes. TDS indicated that salinity varied by less than $20 \%$ during the monitored period. The waters showing most variability with time came from boreholes \#7, \#13 and \#17. There was no general pattern of salinity increase; some boreholes (e.g. \#15 and \#35) exhibited a slight increase, some (e.g. \#29 and \#48) showed a slight decrease, while others fluctuated from one survey to another. Looking at binary diagrams for January 1999 to October 2001, the distribution of chemical composition of waters was more consistent in October 2001 (Figure 6). It is likely that there was a purer Vanur chemical signature, with less input from other kinds of water, and reflecting the recharge water input from the 1998-1999 winter monsoon from the unconfined Vanur. Time variations of the concentrations of $\mathrm{Na}^{+}, \mathrm{Cl}^{-}$, and $\mathrm{SO}_{4}{ }^{2-}$ (Table 2) confirm the TDS results. These results also confirm the input of recharge waters in the deepest parts of the aquifer (e.g. \#13 and \#29). The chemical characteristics of the samples from \#35 and \#26 (Figure 6) initially differed from those of the other boreholes but were similar in October 2001. In January 1999, \#7 seems to have been replenished with saline water from the Kaluvelly swamp (Table 2 and d'Ozouville et al., 2006). This input dropped sharply after October 2000.

Variation in salinity in the other aquifers (Cuddalore, Kadaperikuppam, Ottai, Turuvai and charnockite), based on TDS, was larger than in the Vanur. In the Cuddalore, Kadaperikuppam, Ottai and charnockite aquifers, variation rose to $30 \%$, 50\%, and $100 \%$ (Table 2). As in the Vanur aquifer, there was no general trend towards increased salinity. 


\section{Strontium isotope data}

The ${ }^{87} \mathrm{Sr} /{ }^{86} \mathrm{Sr}$ ratios and Sr concentrations are presented in Table $3 .{ }^{87} \mathrm{Sr} /{ }^{86} \mathrm{Sr}$ ratios were determined first in a few samples from the 2000 and 2001 campaigns to confirm that this ratio behaves as a "conservative” hydrological tracer. According to Figure $8 \mathrm{a}$, the ${ }^{87} \mathrm{Sr} /{ }^{86} \mathrm{Sr}$ ratio should not vary through time at the considered scale.

The samples taken from the three main aquifers (Vanur, Cuddalore and charnockite) displayed contrasting signatures (d'Ozouville et al. 2006). The Sr concentrations of the Vanur waters did not show any significant variations as compared to those in the Cuddalore waters (Table 3) but tended to increase from unconfined to confined areas (see Figure 7 in d'Ozouville et al., 2006). All the samples, except those from \#47 and \#48, displayed higher ${ }^{87} \mathrm{Sr} /{ }^{86} \mathrm{Sr}$ ratios than that of present-day seawater.

The Cuddalore waters showed nearly constant intermediate ${ }^{87} \mathrm{Sr} /{ }^{86} \mathrm{Sr}$ ratios with variable $\mathrm{Sr}$ concentrations, down to very Sr-depleted $(1.01 \mu \mathrm{mol} / \mathrm{L})$, demonstrating the influence of recharge (by rainfall). The recharge was recorded from samples with low Sr contents and ${ }^{87} \mathrm{Sr} /{ }^{86} \mathrm{Sr}$ ratios close to that of seawater, since rainfall has an ${ }^{87} \mathrm{Sr} /{ }^{86} \mathrm{Sr}$ ratio close to that of seawater, as measured during this study $(0.709199 \pm 0.000008)$ and published elsewhere (Dia et al., 1992; Davis et al., 2003; Banner, 2004).

The Sr contents of the charnockite water samples were in the same range as those of Vanur samples. However, they presented large ${ }^{87} \mathrm{Sr} /{ }^{86} \mathrm{Sr}$ ratio variations (from $0.712403 \pm 0.000008$ to $0.705761 \pm 0.000009$ ) (Table 3 ), as did those of the surrounding charnockitic rocks (from $0.706954 \pm 0.000007$ to $0.727856 \pm .0 .000007$ ) (Table 5).

The surface waters displayed rather low Sr contents, indicating recharge by diluted waters (i.e. rainfall) and ${ }^{87} \mathrm{Sr} /{ }^{86} \mathrm{Sr}$ ratios close to (but slightly higher than) seawater values (Table 3).

\section{6. $\delta \mathrm{D}$ and $\delta^{18} \mathrm{O}$ data}

$\delta^{18} \mathrm{O}$ and $\delta \mathrm{D}$ signatures of water bodies were used to characterize evaporation or waterrock interaction processes (Table 2). No local rainfall data were available. Because precipitation is brought mainly by the NE monsoon (Pondicherry meteorological station), the published rainfall data from Sri Lanka (at Colombo and Puttalam, from 1992 to 1995: I.A.E.A., 2002) are thought to be representative of the rainfall received by the Kaluvelly watershed and were used to define a local meteoric water line: $\delta \mathrm{D}=7.6 \delta^{18} \mathrm{O}+7.8$ 
(d'Ozouville et al., 2006). Local rainfall sampled during this study (September 2000, June 2001 and October 2001) was distributed along this line, confirming this hypothesis (Figure 9).

No evaporation process could be identified for erys and groundwater samples collected in January 1999 (Figure 9a). For October 2000, the enrichment in ${ }^{18} \mathrm{O}$ compared to the local water line indicates some degree of evaporation, mainly for samples collected from boreholes \#11, \#23, \#24, \#30 and \#33 (Figure 9b). In January 2001, after a small monsoon, evaporation was still noticeable, mainly for boreholes \#11 and \#24 (Figure 9c). These results reflect the small recharge of erys observed at this period. Distribution of chloride concentrations based on $\delta^{18} \mathrm{O}$ (Figure 9d) allowed two groups of deep boreholes in the Vanur aquifer to be differentiated: those from the eastern area (\#47, \#48), and those from the western area (\#13, \#29). Because of their mixed origin, waters from \#35 appeared in the eastern group. Distribution of chloride and $\delta^{18} \mathrm{O}$ in the Vanur samples did not show the usual positive pattern observed during water evaporation. Mixings between different recharge waters (MEW, waters from the Vanur recharge area, Cuddalore waters) and seawater were tested (Figure 9d). Data distribution did not assess any significant input of seawater in the Vanur aquifer but assessed a more important contribution from the Cuddalore waters in \#47 and \#48 (east) than in \#13 and \#29 (west). This result is in accordance with major element ratios (Figure 6).

Main groundwater samples were distributed along the local meteoric water line, indicating a meteoric origin of the water. The transfer of water (rainfall plus irrigation water) during infiltration does not record physical evaporation. This result has been observed previously in similar areas in India (Gupta et al., 2005; Négrel et al., 2007). However, we have no information about transpiration. The meteoric signature also reflects the low topography of this area (little surface run-off).

\section{Fertilizers}

Samples of a number of commonly used fertilizers were collected in order to determine whether agricultural practices had an impact on the chemical and isotopic signatures of the aquifer waters. Major ions, nitrate and Sr isotopes were measured (Table 4).

The strontium isotope composition of these fertilizers was determined by identifying specific end-members characterized by Sr isotope signature. Sr isotope ratios of fertilizers can be divided into two groups (Table 4): (i) radiogenic, with values up to 0.722003 and corresponding to Cl-rich fertilizers, and (ii) non-radiogenic ratios of around 0.7078 corresponding to previously recorded values (Négrel and Deschamps, 1996; Bölke and Horan, 
2000) and not containing chloride. The first group could correspond to values registered elsewhere in intensively cultivated areas using fertilizers composed of a mixture of dolomite and potash (Bölke and Horan, 2000). By contrast, the second group is commonly found for phosphorus-bearing components used in the production of nitrogen fertilizers (Négrel and Deschamps, 1996; Bölke and Horan, 2000). They exhibit Sr isotope ratios similar to early Tertiary marine values (Banner, 2004). Samples from \#16 in the Vanur aquifer contained both chloride and nitrate with a high ${ }^{87} \mathrm{Sr} /{ }^{86} \mathrm{Sr}$ ratio, suggesting contamination by a fertilizer from the first group. However, it should be kept in mind that as we did not have access to complete sets of archived fertilizers, it was not possible to determine whether the groundwater $\mathrm{Sr}$ isotope ratios were matched over space and time by those of agricultural applications. However, these two extreme values for fertilizers match the data and correspond to analyses of fertilizers in the literature.

\section{Charnockite composition}

Charnockite rocks were also collected: two samples of black charnockite (Kunnam, near \#31) and one of pink charnockite (Perimukal, near \#23) (Figure 1). Charnockite rocks were mainly black at the outcrop, but we have no information about charnockites overlaid by the Vanur aquifer. The mineralogical composition of these rocks (modal) showed that these charnockites were silica-rich, with 50 to $70 \%$ v/v of alkali feldspars, 30 to $20 \% \mathrm{v} / \mathrm{v}$ of quartz, 15 to $5 \% \mathrm{v} / \mathrm{v}$ of plagioclase (Table 5). Ferromagnesian minerals were biotite, pyroxene and amphibole.

\section{DISCUSSION}

Proximity to the sea, landscape morphology and geometry of the sedimentary formations suggest several processes that could account for the salinity in the Vanur aquifer. These include: (i) direct seawater intrusion, or (ii) seawater intrusion through the upper aquifers bordering the coast, (iii) recharge with brackish waters from the swamp, north of the watershed, or (iv) upward leakage of deep long-residence time waters from the Vanur aquifer or an underlying aquifer. The change in hydraulic gradient could also have caused a flow of saline water coming from north or south of the catchment (Natarajan et al., 2003). In addition, the intensification of agriculture in this area could have affected the water quality of the aquifers. Examination of the whole dataset allowed us to test five hypotheses regarding the source of salinity in the Kaluvelly watershed: (i) evaporation, (ii) direct seawater intrusion, or 
intrusion through the upper aquifer bordering the coast (alluvium and dunes) or through the Kaluvelly swamp, (iii) long-term water-rock interaction, (iv) intrusion of deep saline water from surrounding aquifers, and (v) intensive agriculture.

\section{Evaporation}

Evaporation increases the concentration of solutes in water and enriches the solution in heavy oxygen isotopes (such as ${ }^{18} \mathrm{O}$ ), but does not significantly modify ${ }^{87} \mathrm{Sr} /{ }^{86} \mathrm{Sr}$ ratios. Our data cannot therefore be explained by evaporation phenomena; $\delta \mathrm{D}$ and $\delta^{18} \mathrm{O}$ data indicate that only a few samples (mainly from October 2000, Figure 9b) may have experienced slight evaporation.

It is therefore impossible for physical evaporation alone to be responsible for the salinity variations observed from one aquifer to another or within one aquifer over time. However, in an isotopic steady-state condition of plant water, no fractionation occurs between root water and vapor during transpiration. Thus, the quality of recharge waters must have been modified by biological uptake.

\section{Direct or indirect seawater intrusion}

Sodium and $\mathrm{Cl}^{-}$concentrations (Figure 5a) were not on the mixing line between recharge waters (MEW) and seawater (ASW); sodium was enriched as compared to $\mathrm{Cl}^{-}$with the exception of samples from \#16, \#32, \#33, and \#40. Likewise, the distribution of sulphate and chloride (Figure 7) cannot be explained by seawater intrusion as the ratio of sulphate to chloride in these waters was higher than that of seawater. Only samples from \#16 and \#33 exhibited a $\mathrm{SO}_{4} / \mathrm{Cl}$ ratio similar to that of seawater, but their ${ }^{87} \mathrm{Sr} /{ }^{86} \mathrm{Sr}$ ratio was higher than that of seawater (Figure 8). These are suspected to be mixed with irrigation waters (Figure 5b). The swamp signature could be considered to arise from a mixing of seawater and charnockite-influenced waters, which is likely to be the result of run-off on the charnockite outcrop. Concentrations, major element ratios, and ${ }^{87} \mathrm{Sr} /{ }^{86} \mathrm{Sr}$ ratios thus conflict with the seawater intrusion hypothesis. If seawater intrusion did occur, it was not noticeable in the water quality. 


\section{Long-term water-rock interaction - The major compound record}

To model the equilibrium state of the water, we assumed that the water-rock interaction has sufficiently progressed to record a chemical signature (for cations and dissolved silica as well) mainly derived from rock dissolution. In the interacting water, the increase in cation concentration occurs at different rates depending on the minerals involved. In the Vanur aquifer, $\mathrm{Na}^{+}$and $\mathrm{Cl}^{-}$concentrations indicate an increase in TDS from the recharge area to the deep parts (Figure 5a). The $\mathrm{Ca} / \mathrm{Mg}$ ratio was stable (Figure 6) and the $\mathrm{Mg} / \mathrm{K}$ ratio tended to slightly increase, corresponding to chemical changes in the water during weathering. A secondary phyllosilicate, together with chalcedony and an aluminium mineral or lowtemperature albite are needed to test the equilibrium state of the water. In a study of the weathering of gneissic rocks in south India, Sharma and Rajamani (2000) found that the secondary minerals commonly formed from charnockite weathering were chlorite, smectite, kaolinite and Fe-oxyhydroxide. Thermodynamic calculations (PHREEQC version 2, Parkhurst and Appelo, 1999) showed that the Vanur waters were not in equilibrium with chlorite, as their Mg concentrations were too high. From potential calcite precipitation in several boreholes and waters in equilibrium with a high $\mathrm{pCO}_{2}$, we can hypothesize that the Ca-silicate secondary mineral precipitation was delayed. We also tested the equilibrium state of water using a mineral stability diagram depicting the gibbsite - kaolinite - Na-smectite albite system plotted on a $\log \left(\left[\mathrm{Na}^{+}\right] /\left[\mathrm{H}^{+}\right]\right)$versus $\log \left(\left[\mathrm{H}_{4} \mathrm{SiO}_{4}\right]\right)$ diagram (Figure 10) (controlled elements: $\mathrm{Na}, \mathrm{Al}$ and $\mathrm{Si}$ ). We used thermodynamic data from WATEQ4F (Ball and Nordstrom, 1991) and from Vieillard (2002) for Na-smectite. Without $\Delta H$ values, reactions were assumed to occur at $25^{\circ} \mathrm{C}$ and $1 \mathrm{~atm}$. We chose the following Na-smectite composition: $\mathrm{Na}_{0.6}\left(\mathrm{Al}_{1.65} \mathrm{Mg}_{0.35}\right)\left(\mathrm{Al}_{0.25} \mathrm{Si}_{3.75}\right) \mathrm{O}_{10}(\mathrm{OH})_{2}$. The limits of the Na-smectite field depend on the concentrations of $\mathrm{Na}^{+}, \mathrm{H}_{4} \mathrm{SiO}_{4}, \mathrm{Mg}^{2+}$ and $\mathrm{pH}$. For the Vanur waters, four extreme values were used: $\mathrm{pH}$ between 6.6 and 7.0; concentration of $\mathrm{Mg}^{2+}$ between 1.00 and $3.60 \mathrm{mmol} / \mathrm{L}$. These generated four lines for each limit. The Vanur waters were at the limit between Na-smectite and albite and on the equilibrium line of amorphous silica. Output temperatures were between 28 and $34^{\circ} \mathrm{C}$, indicating that the aquifer temperature might be about $34^{\circ} \mathrm{C}$ at least (because $\mathrm{CO}_{2}$ degassing involves water cooling). Consequently, we also needed to consider a slight upward shift of the field limits. Figure 10 shows that the Vanur waters were in equilibrium with a mineral association such as Na-smectite- albite-amorphous silica (or chalcedony for some waters).

If water-rock interactions can explain the cation composition, it cannot explain the high $\mathrm{SO}_{4}$ content of the Vanur waters. The deepest waters from the Vanur aquifer exhibited the 
highest $\mathrm{SO}_{4} / \mathrm{Cl}$ ratio (Figure 7) with a maximum of 0.80 measured in HA13. However, there is no report in the literature of any sulphide mineral in the Vanur sandstone. Sulphate can be considered as a purely mobile compound, such as chloride, if the water is sufficiently oxidative. Its concentration will increase with time by accumulation, such as that of chloride. Aquifer geometry and the nature of the top formations (clays) suggest that water has accumulated in the Vanur aquifer for several hundreds or thousands of years, leading to a considerable accumulation of sulphate and chloride. The Cuddalore aquifer and the recharge area of the Vanur aquifer show a similar range of $\mathrm{SO}_{4} / \mathrm{Cl}$ ratios $(0.05$ to 0.20$)$. The maximum $\mathrm{SO}_{4} / \mathrm{Cl}$ ratios measured in the charnockite aquifer were smaller than the maximum value in the Vanur (Figure 7), but a considerable input of chloride- and nitrate-rich irrigation water is suspected in several charnockite boreholes (Figure 5b). Two sources of this sulphate enrichment have been hypothesized (d'Ozouville et al., 2006): (i) mixing with Ottai-like water (from \#37, maximum ratio measured equal to 1.20), or (ii) mixing with the Ramanathapuram aquifer where the sandstone contains lignite. However, we had no clear criteria enabling us to choose between these two possibilities (there is no borehole in the Ramanathapuram aquifer). The two rainwater samples (HB R1 and HD R1) exhibited a $\mathrm{SO}_{4} / \mathrm{Cl}$ ratio from 0.33 to 0.56 (Figure 7 ). $\delta^{18} \mathrm{O}$ and $\delta \mathrm{D}$ data (Figure 9) suggest that the recharge waters of the Vanur have come from the same meteorological source (all data fall on the present-day meteoric water line) for several hundreds/thousands of years. This raises the question of whether the natural $\mathrm{SO}_{4} / \mathrm{Cl}$ ratio of precipitation has remained constant over time. $\mathrm{SO}_{4} / \mathrm{Cl}$ ratios recorded in the aquifer may thus be partly linked to meteoric input.

\section{Long-term water-rock interaction - The isotope record}

Groundwater acquires dissolved $\mathrm{Sr}$ at the recharge area during infiltration and percolation, and along the flow paths through dissolution of minerals and/or ion exchange. Thus, $\mathrm{Sr}$ isotope data provide a sort of integrated flow-path signal of water-rock interaction rather than a true conservative tracer. Strontium isotopes can be considered to give a diagnostic signal of the source of dissolved constituents that could not be obtained from the study of major- or trace-element variations alone. Previous studies of $\mathrm{Sr}$ isotope fingerprinting have demonstrated the usefulness of this tracer in groundwater studies (Négrel and Deschamps, 1996; Négrel et al., 2000; 2003; Semhi et al., 2000; Ojiambo et al., 2003 and references therein). Accordingly, we used ${ }^{87} \mathrm{Sr} /{ }^{86} \mathrm{Sr}$ ratios in this study to monitor the mixing between the different involved end-members. 
All the Vanur samples followed a trend from the confined to the recharge area, confirming the importance of water-rock interaction in the global signature of these waters. Their ${ }^{87} \mathrm{Sr} /{ }^{86} \mathrm{Sr}$ ratios were higher than that of the present-day seawater value, with the exception of the samples from \#47 and \#48, suggesting that the latter are not influenced by present-day seawater (d'Ozouville et al., 2006). Their ${ }^{87} \mathrm{Sr} /{ }^{86} \mathrm{Sr}$ ratios were probably due to mixing with a low radiogenic component such as the charnockite aquifer, as here below described.

The Sr signature of Cuddalore water was very different from that of Vanur water from both the confined and the recharge areas.

The charnockite water samples were characterized by a Sr content comparable to that of the Vanur samples, but with significant ${ }^{87} \mathrm{Sr} /{ }^{86} \mathrm{Sr}$ ratio variations (d’Ozouville et al., 2006) which mimic the broad spread of variations in the ${ }^{87} \mathrm{Sr} /{ }^{86} \mathrm{Sr}$ ratios of charnockitic rock (Table 5). The charnockitic rocks sampled during this work showed ${ }^{87} \mathrm{Sr} /{ }^{86} \mathrm{Sr}$ ratios ranging between 0.706954 and 0.727856 (Table 5). The literature reports ${ }^{87} \mathrm{Sr} /{ }^{86} \mathrm{Sr}$ ratios of granulite rocks as low as 0.702 (Peucat et al., 1989). Most of the charnockite aquifer samples showed ${ }^{87} \mathrm{Sr} /{ }^{86} \mathrm{Sr}$ ratios below the seawater value, suggesting a low charnockitic end-member. However, some samples had values above the seawater value suggesting either a mixing with the Vanur endmember, or the influence of a higher charnockitic end-member, or possibly anthropogenic contamination, as some fertilizers had ${ }^{87} \mathrm{Sr} /{ }^{86} \mathrm{Sr}$ ratios of up to 0.72203 (see data for fertilizer samples Fert2, Fert4 and Fert8 in Table 4) and high contents in both chloride and nitrate (Figure 5b).

The ${ }^{87} \mathrm{Sr} /{ }^{86} \mathrm{Sr}$ ratios thus help distinguish between the Vanur, Cuddalore (and associated recharge) and charnockite (low radiogenic) end-members, as previously described (d'Ozouville et al., 2006). Further to these earlier results, the ${ }^{87} \mathrm{Sr} /{ }^{86} \mathrm{Sr}$ ratio dataset as a whole suggests that water from the charnockite and Vanur aquifers is mixed, as the values of the Vanur samples from the confined area are between those of the charnockite end-member and of the free water table from the Vanur aquifer. The strontium dataset confirmed the importance of water-rock interaction in the composition of Vanur waters, as also shown by major compounds.

\section{Influence of human activity}

Major and minor compounds were used to assess local anthropogenic input in surface waters (e.g. \# 8, the swamp) and in some shallow boreholes in the Cuddalore, Vanur and charnockite (6 out of 8) aquifers. The chloride content of \#23, 32, 50, 52 and 35 could be 
linked to irrigation water, as suggested by Figure 5b, but does not originate from Fert2, Fert4 or Fert8 fertilizers (Figure 8b), whereas it does in \#16. It is possible that other sources such as animal manure are involved, but it is difficult to use the ${ }^{87} \mathrm{Sr} /{ }^{86} \mathrm{Sr}$ signature, as the only input related to human activity analyzed were fertilizers. Moreover, there is no Sr isotope data related to possible industrial activity.

Surface water showed low Sr contents, indicating recharge by dilute waters (i.e. rainfall), and ${ }^{87} \mathrm{Sr} /{ }^{86} \mathrm{Sr}$ ratios close to (but slightly higher than) the seawater value. This shift from the seawater value might be due to anthropogenic contamination. However, since the fertilizers displayed both radiogenic and non-radiogenic values ranging between 0.707838 and 722003 , it is not possible to deduce this type of human influence from Sr isotope ratios. Therefore, either the anthropogenic contamination was not related to fertilizer use but to another unidentified human source, industrial for example, or another tracer needs to be found in order to identify allochtonous input to the hydrosystem.

The high $\mathrm{SO}_{4} / \mathrm{Cl}$ ratio recorded in rainwater may be linked to the use of fertilizers such as $\left(\mathrm{NH}_{4}\right)_{2} \mathrm{SO}_{4}$, as observed in the Western Ghats (Jacks et al., 1994), or Fert3 or Fert9 (Table 4). In addition, an increase in sulphate from fossil fuel combustion has been observed in precipitation over the Bay of Bengal (Safai et al., 2004; Reddy et al. 2008). This atmospheric sulphate may therefore have caused the aquifer signature, but only in the upper parts because this use is recent.

\section{CONCLUSION}

From January 1999 to October 2001, no increase in salinization occurred in the Vanur aquifer. Salinity was not linked to physical evaporation or seawater intrusion (direct or indirect). During this period, the chemical composition of waters became more consistent and less affected by input from other aquifers, which is consistent with the input of new recharge water after several rainfall-deficient years (1995 to 1998), even in the deepest parts of the aquifer. However, in these deepest parts, chemical and isotope data show considerable heterogeneity. This could be linked to lithological heterogeneity, time transfer, a mixing with other aquifers, or disconnection/isolation due to pumping. Concentrations and ratios of major compounds, together with Sr isotopes, indicate that the water quality of the Vanur sandstone aquifer is mainly linked to recharge water quality plus water-rock interaction. Mixings between aquifers fluctuate according to season and monsoon but are of limited importance 
with the possible exception of some boreholes (\#26, 35, 47 and 48). Some swamp input was recorded in \#7 in January 1999.

The high $\mathrm{SO}_{4} / \mathrm{Cl}$ ratios recorded in the Vanur aquifer due to sulphate enrichment could be linked to mixing with Ottai-like water (such as \#37), or mixing with the Ramanathapuram aquifer which contains lignite. However, some of the sulphate derives from meteoric input and fertilizer use.

In the Vanur aquifer, three samples displayed different signatures. Major compounds and isotope data suggest that borehole \#16 was contaminated by anthropogenic input such as $\mathrm{KCl}$. Boreholes \#47 and \#48 displayed low $\mathrm{Mg} / \mathrm{K}$ and relatively high $\mathrm{Ca} / \mathrm{Mg}$ ratios, and ${ }^{87} \mathrm{Sr} /{ }^{86} \mathrm{Sr}$ ratios lower than that of seawater. Strontium isotopes suggest a mixing with the low ${ }^{87} \mathrm{Sr} /{ }^{86} \mathrm{Sr}$ ratio charnockite water, while major elements suggest a mixing with Cuddalore water. Chloride and nitrate-rich irrigation waters were recorded in most of the charnockite boreholes, but the original ${ }^{87} \mathrm{Sr} /{ }^{86} \mathrm{Sr}$ ratios seem to have been preserved.

This study demonstrates that it is possible to describe the mixing of water from different aquifers using agricultural boreholes and a few geochemical tools with a moderate number of samples. However, to get larger understanding of water circulation, another study focused on trace elements in both the host-rocks and water is in progress.

\section{ACKNOWLEDGEMENTS}

This work was supported by the UMR-Sisyphe, the GéEAC, Harvest AWS (field and data-base collection logistics), NEB (grant for 1999 survey), and a CNRS-INSU grant (ACI Eau, 2000-2002). We thank G. de Marsily, T. Gablier, G. Boulicot and N. Jendrzejewski for their kind support. Cation analyses were performed thanks to free access to the Analytical Chemistry Laboratory of the Pharmacy Faculty (University of Tours, Prof. P. Dubois). We thank M. Bouhnik-LeCoz, O. Henin and J. Macé in the Geosciences department in Rennes for their assistance with analytical work on Sr concentration determination by ICP-MS and Sr isotope ratio measurements by TIMS. The $\delta^{18} \mathrm{O}$ analyses of the HA series waters were performed by N. Jendrzewski and the Laboratoire de Géochimie des Isotopes Stables, Institut de Physique du Globe de Paris.

\section{References}


Ball J. W., Nordstrom D.K., 1991. WATEQ4F - User's manual with revised thermodynamic data base and test cases for calculating speciation of major, trace and redox elements in natural waters: U.S. Geological Survey Open-File Report 90-129, 185p.

Banner J.L., 2004. Radiogenic isotopes: systematics and applications to Earth surface processes and chemical stratigraphy. Earth Science Review 65, 141-194.

Berner E.K., Berner R.A., 1996. Global environment: water, air, and geochemical cycles. The Prentice-Hall Inc., Upper Saddle river, pp312-363.

Bölke J.K., Horan M., 2000. Strontium isotope geochemistry of groundwaters and streams affected by agriculture, Locust Grove, MD. Applied Geochemistry 15, 599-609.

Capaccioni B., Didero M., Paletta C., Didero L., 2005. Saline intrusion and refreshening in a multilayer coastal aquifer in the Catania Plain (Sicily, Southern Italy): dynamics of degradation processes according to the hydrochemical characteristics of groundwaters. Journal of Hydrology 307, 1-16.

Coleman M.L., Sheppard T.J., Durham J.J., Rouse J.E., Moore G.R., 1982. Reaction of water with zinc for hydrogen isotopes analysis. Analytical Chemistry 54, 993-995.

Darwish T., Atallah T., El Moujabber M., Khatib N., 2005. Salinity evolution and crop response to secondary soil salinity in two agro-climatic zones in Lebanon. Agriculture Water Management 78, 152-164.

Davis A.C., Bickle M.J., Teagle D.A.H., 2003. Imbalance in the oceanic strontium budget. Earth Planetary Science Letters 211, 173-187.

Dia A., Cohen A.S., O’Nions R.K., Shackelton N.J., 1992. Seawater Sr isotope variations over the past $300 \mathrm{kyr}$ and influence of global climate cycles. Nature 356, 786-788.

D’Ozouville N., Violette S., Gassama N., Dia A., Jendrzejewski N., 2006. Origin and modelling of water salinization in a coastal aquifer of the Bay of Bengal: The Kaluvelly watershed, Tamil Nadu, India. Bulletin de la Société Géologique de France 177 (6), 333345.

Edmunds W.M., 2003. Renewable and non-renewable groundwater in semi-arid and arid regions. Development Water Sciences 50, 265-280.

Epstein S., Mayeda T.K., 1953. Variations of the ${ }^{18} \mathrm{O} /{ }^{16} \mathrm{O}$ ratio in natural waters. Geochimica et Cosmochimica Acta 4, 213.

Faye S., Maloszewski P., Stichler W., Trimborn P., Cissé Faye S., Bécaye Gaye C., 2005. Groundwater salinizzation in the Saloum (Senegal) delta aquifer: minor elements and isotopic indicators. Science of the Total Environment 343, 243-259.

Gablier T., Krishnamoorthy A., Siva Subramanian, 2000. Water quality scenario in the first Federation of Kaluvelly watershed, Vanur Taluk, Villupuram district. Harvest, AWS, 1996-2000, 55p

Gupta S.K., Deshpande R.D., Bhattacharya S.K., Jani R.A., 2005. Groundwater $\delta^{18} \mathrm{O}$ and $\delta \mathrm{D}$ from central Indian Pninsula: influence of the Arabian Sea and the Bay of Bengal branches of the summer monsoon. Journal of Hydrology 303, 38-55.

Herczeg A.L., Dogramaci S.S., Leaney W.J., 2001. Origin of dissolved salts in a large, semiarid groundwater system: Murray Basin, Australia. Marine and Freshwater Research 52, 41-52.

Horita J., Ueda A., Mizukami K., Takatori I., 1989. Automatic $\delta \mathrm{D}$ and $\delta^{18} \mathrm{O}$ analyses of multiwater samples using $\mathrm{H}_{2}$ and $\mathrm{CO}_{2}$ water equilibration methods with a common equilibration set-up. Applied Radiation and Isotope 40 (9), 801-805.

IAEA, 2002. Global Network of Isotopes in Precipitation. The GNIP Database. Accessible at: http://isohis.iaea.org 
Jacks G., Sharma V.P., Torssander P., Åberg G., 1994. Origin of sulphur in soil and water in a Precambrian terrain, S. India. Geochemical Journal 28, 351-358.

Jaya Kumar B., Chandra P.C., Veeranjaneyulu D., Adil Md., Narayana Raju V., Tata S.N., 1984. Hydrological conditions in Auroville. Government of India, Central Ground Water Board, Ministry of Agriculture and Irrigation, Department of Agriculture, Southern region, Hyderabad, May 1984, Report,124p.

Khan S., Hanjra M.A., 2008. Sustainable land and water management policies and practices: a pathway to environmental sustainability in large irrigation systems. Land Degradation \& Development 19, 469-487.

Kim, Y., Lee K.-S., Koh D.-C., Lee D.-H., Lee S.-G., Park W.-B., Koh G.-W., Woo N.-C., 2003. Hydrogeochemical and isotopic evidence of groundwater salinization in a coastal aquifer: a case study in Jeju volcanic island, Korea. Journal of Hydrology 270, 282-294.

Krupanidhi K.V.J.R., Sankaran M., Natarajan P., 1979. Report on the scope for further groundwater development in Pondicherry region, Union Territory of Pondicherry, field season 1973-1976. Government of India, Central Ground Water Board, Ministry of Agriculture and Irrigation, department of Agriculture, Southern region, Hyderabad, November 1979, 40p.

Morell I., Giménez E., Esteller M.V. 1996. Application of principal components analysis to the study of salinization on the Castellon Plain (Spain). Science of the Total Environment 177, 161-171.

Naftz D. L., Peterman Z. E., Spangler L. E., 1997. Using ${ }^{87}$ Sr values to identify sources of salinity to a freshwater aquifer, Greater Aneth Oil Field, Utah, USA. Chemical Geology 141(3-4), 195-209.

Natarajan P.M., Kallolikar S., Ambalavanan P.M.N., 2003. Remote sensing and geographic information system approaches for the identification and monitoring the poor quality groundwater regions of Tamil Nadu. $2^{\text {nd }}$ International Conference on 'Water Quality Management”, 13-15 February 2003, New Delhi, India. Ed: G.N. Mathur and Dr A.S. Chawla, III-65-III-76.

Négrel P., Deschamps P., 1996. Natural and anthropogenic budgets of a small watershed in the Massif Central (France): chemical and strontium isotopic characterization of water and sediments. Aquatic Geochemistry 2, 1-27.

Négrel P., Grosbois C., Kloppmann W., 2000. The labile fraction of suspended matter in the Loire (France): multi-element chemistry and isotopic (Rb-Sr and C-O) systematics. Chemical Geology 166, 271-285.

Négrel Ph., Lemière B., Machard de Grammont H., Billaud P., Sengupta B., 2007. Hydrogeochemical processes, mixing and isotope tracing in hard rock aquifers and surface waters from the Subarnarekha River Basin (east Singhbhum District, Jharkhand State, India). Hydrogeology Journal 15, 1535-1552.

Négrel P., Pételet-Giraud E., Barbier J., Gautier E., 2003. Surface water-groundwater interactions in an alluvial plain: chemical and isotopic systematics. Journal of Hydrology 277, 248-267.

Oren O., Yechieli Y., Böhlke J. K., Dody A., 2004. Contamination of groundwater under cultivated fields in an arid environment, central Arava Valley, Israel. Journal of Hydrology 290 (3-4), 312-328.

Ojiambo S.B. , Berry Lyons W., Welch K.A., Poreda R. J., Johannesson K. H., 2003. Strontium isotopes and rare earth elements as tracers of groundwater-lake water interactions; lake Naivasha, Kenya. Applied Geochemistry 18, 1789-1805. 
Park S.-C., Yun S.-T., Chae G.-T., Yoo I.-S., Shin K.-S., Heo C.-H., Lee S.-K., 2005. Regional hydrochemical study on salinization of coastal aquifers, western coastal area of South Korea. Journal of Hydrology 313, 182-194.

Parkhurst D.L., Appelo C.A.J., 1999. User’s guide to PHREEQC (version 2) - a computer program for speciation, batch-reaction, one-dimensional transport, and inverse geochemical calculations: U.S. Geological Survey Water-Resources Investigations Report 99-4259, 312p.

Petheram C., Bristow K.L., Nelson P.N., 2008. Understanding and managing groundwater and salinity in a tropical conjunctive water use irrigation district. Agriculture and Water Management 95, 1167-1179.

Peucat J.J., Vidal P., Bernard-Griffiths J., Condie K.C, 1989. Sr, Nd and Pb isotopic systematics in the Archean low- to high-grade transition zone of southern India: synaccretion vs. post-accretion granulites. Journal of Geology 97, 537-550.

Pin C., Briot D., Bassin C., Poitrasson F., 1994. Concomittant separation of strontium and samarium-neodymium for isotopic analysis in silicate samples based on specific extraction chromatography. Analytica Chimica Acta 298, 209-217.

Pougajendy V., Murugaian R., Gablier T., 1997a. Grounwater extraction cum salinity survey a part of Vanur and Tindivanam Taluk. Harvest, AWS, 1995-1997, 30p.

Pougajendy V., Murugaian R., Gablier T., 1997b. A preliminary study on ground water quality (salinity) in the southern \& eastern banks' villages of the Kaluvelly swamp. Harvest, AWS, 1997, 32p.

Pulido-Leboeuf P., 2004. Seawater intrusion and associated processes in a small coastal complex aquifer (Castell de Ferro, Spain). Applied Geochemistry 19(10), 1517-1527.

Reddy D. R., Rao T. S., 1997. Echo characters of the continental margin, western Bay of Bengal, India. Marine Geology 140, 201-217.

Reddy L.A.K., Kulshrestha U.C., Satyanarayana J., Kulshrestha M.J., Moorthy K.K., 2008. Chemical characteristics of $\mathrm{PM}_{10}$ aerosols and airmass trajectories over Bay of Bengal and Arabian Sea during ICARB. Journal Earth System Science 117, 345-352.

Safai P.D., Rao P.S.P., Momin G.A., Ali K., Chate D.M., Praveen P.S., 2004. Chemical composition of precipitation during 1984-2002 at Pune, India. Atmospheric Environment 38, $1705-1714$.

Sanchez Martos F., Pulido Bosch A., Molina Sanchez L., Vallejos-Izquierdo A., 2002. Identification of the origin of salinization in groundwater using minor ions (Lower Andarax, Southeast Spain). Science of the Total Environment 297, 43-58.

Semhi K., Clauer N., Probst J.-L., 2000. Strontium isotope compositions of river water as records of lithology-dependent mass transfers; the Garonne river and its tributaries (SW France). Chemical Geology 168, 173-193.

Sharma A., Rajamani V., 2000. Weathering of gneissic rocks in the upper reaches of Cauvery river, south India: implications to neotectonics of the region. Chemical Geology 166, 203-223.

Shavit U., Furman A., 2001. The location of deep salinity sources in the Israeli Coastal aquifer. Journal of Hydrology 250 (1-4), 67-77.

Shen F., Xiuling C., 2007. Developing drainage as the basis of comprehensive control of drought, waterlogging, salinity and saline groundwater. Irrigation and Drainage 56, S227-S244.

Stigter T.Y., Ribeiro L., Carvalho Dill A.M.M., 2006. Evaluation of an intrinsic and a specific vulnerability assessment method in comparison with groundwater salinisation and nitrate 
contamination levels in two agricultural regions in the south of Portugal. Hydrogeology Journal 14, 79-99.

Stigter T. Y., van Ooijen S. P. J., Post V. E. A., Appelo C. A. J., Carvalho Dill A. M. M., 1998. A hydrogeological and hydrochemical explanation of the groundwater composition under irrigated land in a Mediterranean environment, Algarve, Portugal. Journal of Hydrology 208 (3-4), 262-279.

Sukhija B.S., Reddy D.V., Nagabhushanam P., 1998. Isotopic fingerprints of paleoclimates during the last 30,000 years in deep confined groundwaters of southern India. Quaternary Research 50, 252-260.

Sukhija B.S., Varma V.N., Nagabhushanam P., Reddy D.V., 1996. Differentiation of palaeomarine and modern seawater intruded salinities in coastal groundwaters (of Karaikal and Tanjavur, India) based on inorganic chemistry, organic biomarker fingerprints and radiocarbon dating. Journal of Hydrology 174, 173-201.

Vengosh A., Spivack A.J., Artzi Y., Ayalon A., 1999. Geochemical and boron, strontium, and oxygen isotopic constraints on the origin of the salinity in groundwater from the Mediterranean coast of Israel. Water Resource Research 35 (6), 1877-1894.

Vieillard P., 2002. A new method for the prediction of Gibbs free energies of formation of phyllosilicates ( $10 \AA \& 14 \AA$ ) based on the electronegativity scale. Clays \& Clay Minerals 50 (3), 352-363.

Yoon, J.S., 1986. The factors of saline groundwater in the east area of Cheju Island. Chejudo Research 3, 43-53. (in Korean with an English abstract).

\section{Figure captions}

Figure 1. Sample location in the Kaluvelly watershed (India). Numbers refer to well numbers (see

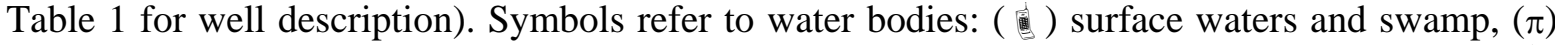
waters from the Cuddalore aquifer, $(\square)$ the Vanur aquifer, ( $\star$ ) the charnockite aquifer and ( from other aquifers.

Figure 2. Extract of the geological map of Tamil Nadu (Geological Survey of India, 1995). The line represents the location of the cross-section here below figured. The basementsediment contact is approximate (no more precise information is available at present time).

Figure 3. Piezometric map of the Vanur aquifer measured in June 2001 (AWS, this study) and location of wells. Numbers refer to wells which were used to draw this map (see Table 1 for well description). The grey area corresponds to the unconfined area of this aquifer.

Figure 4. Distribution of the chemical composition of the Kaluvelly swamp through time. a) $\mathrm{Na}^{+}$versus $\mathrm{Cl}^{-}$concentrations and b) $\mathrm{Ca}^{2+}$ versus $\mathrm{SO}_{4}{ }^{2-}$ concentrations from January 1999 to October 2000. The dashed line corresponds to mixing between an average seawater (ASW from Berner and Berner, 1996) and surface waters (as reported MEW).

Figure 5. a) $\mathrm{Na}^{+}$versus $\mathrm{Cl}^{-}$concentrations in waters sampled in October 2000. The dashed line represents the linear correlation for a mixing between input waters (MEW) and an average seawater (ASW; Berner and Berner, 1996). b) $\mathrm{NO}_{3}{ }^{-}$versus $\mathrm{Cl}^{-}$concentrations in samples collected in January 2001.

Figure 6. $\mathrm{Ca} / \mathrm{Mg}$ versus $\mathrm{Mg} / \mathrm{K}$ ratios for groundwater samples collected a) in October 2000, b) in January 2001, c) in June 2001, d) in October 2001. ASW: average seawater (Berner and Berner, 1996). 
Figure 7. $\mathrm{SO}_{4} / \mathrm{Cl}$ ratios versus $\mathrm{SO}_{4}{ }^{2-}$ concentrations in waters collected in October 2000 . The dashed line represents the seawater ratio. MEW corresponds to the average ery water endmember.

Figure 8. a) ${ }^{87} \mathrm{Sr} /{ }^{86} \mathrm{Sr}$ ratios for samples collected in 2000 are reported versus the ${ }^{87} \mathrm{Sr} /{ }^{86} \mathrm{Sr}$ ratios for the same samples collected in 2001 to evidence the conservative behaviour of the ${ }^{87} \mathrm{Sr} /{ }^{/ 6} \mathrm{Sr}$ ratios for deep aquifer samples. The 1:1 regression line is represented by the black line. b) ${ }^{87} \mathrm{Sr} /{ }^{86} \mathrm{Sr}$ ratios versus $\mathrm{Cl}^{-}$concentrations in samples collected in January 2001. Arrows point out boreholes suspected to have received $\mathrm{NO}_{3}$ - and Cl-rich irrigation waters. Dashed lines represent ${ }^{87} \mathrm{Sr} /{ }^{86} \mathrm{Sr}$ ratios recorded in seawater and in sampled fertilizers. Fertilizers \#Fert3 and Fert9 did not contain any chloride.

Figure 9. Distribution of $\delta^{18} \mathrm{O}$ as a function of $\delta \mathrm{D}$ expressed as \%o versus SMOW. a) in January 1999, b) in October 2000, c) in January 2001 (no rain for January 2001. The rain samples from June and October 2001 were added). The straight line represents the local meteoric line calculated for Sri Lanka (rainfall at Colombo and Puttalam, from 1992 to 1995: I.A.E.A., 2002): $\delta \mathrm{D}=7.5 \delta^{18} \mathrm{O}+7.8\left(\mathrm{R}^{2}=0.907 ; 44\right.$ data points have been used). Arrows help to locate the rain samples. d) Distribution of $\mathrm{Cl}^{-}$concentrations as a function of $\delta^{18} \mathrm{O}$ in samples collected in January 2001. Dashed lines represent mixing between (i) Cuddalore waters and seawater, (ii) Vanur recharge waters and seawater, (iii) MEW and seawater. Numbers on the dashed lines refer to percentage of seawater.

Figure 10. Equilibrium state for waters from the Vanur aquifer (all series) expressed in a gibbsite/kaolinite/Na-smectite/albite stability field diagram. Limits of the Na-smectite field depend also on $\left[\mathrm{Mg}^{2+}\right]$ and $\mathrm{pH}$. See text for further calculation information. 


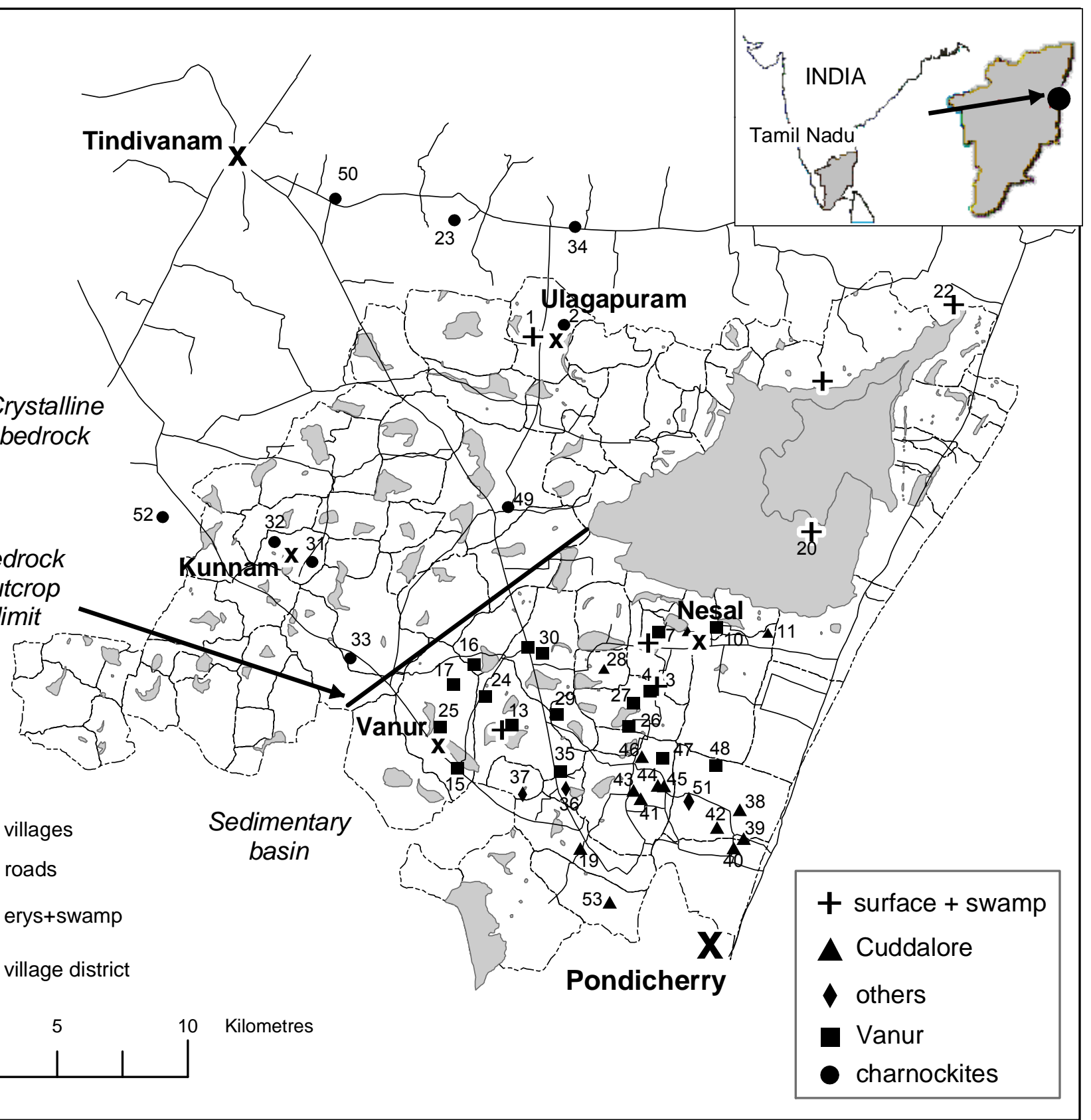




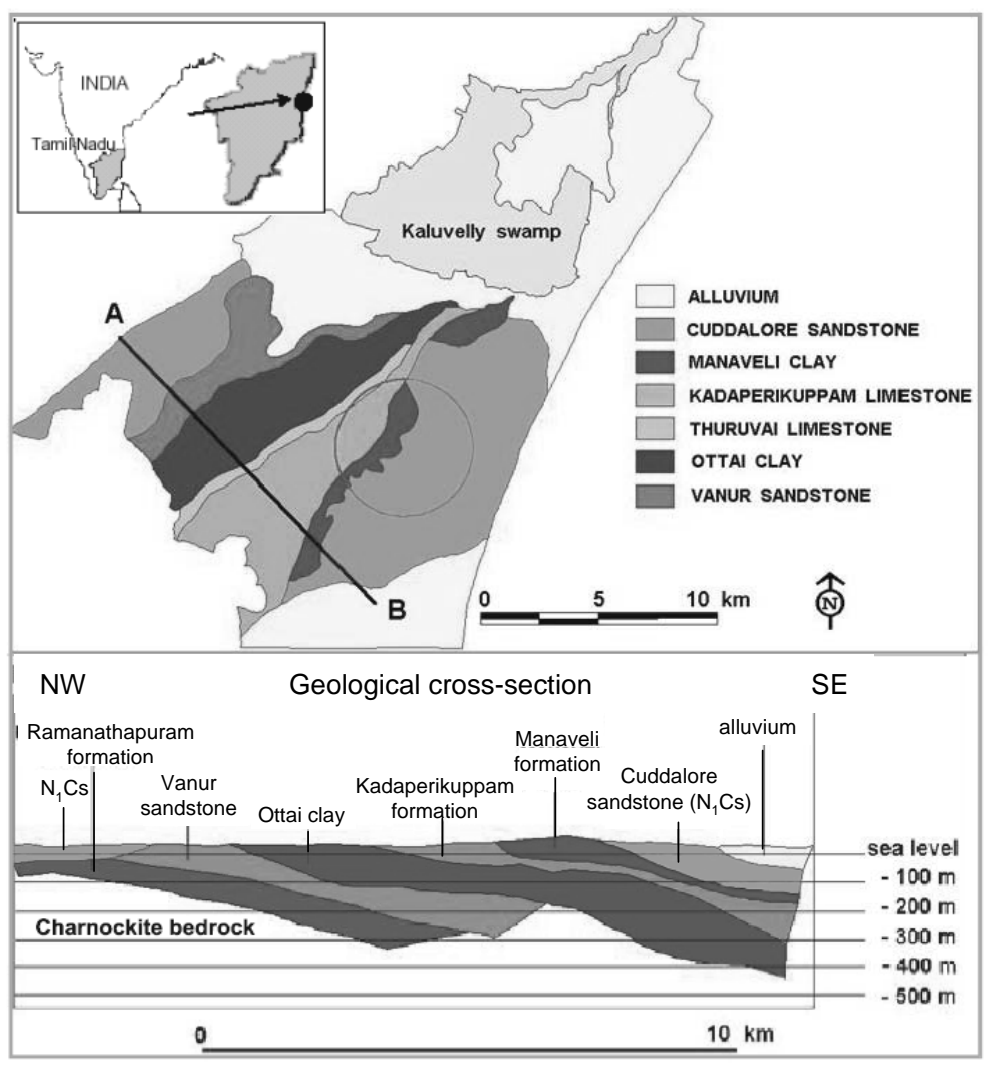

Figure 2 
June 2001

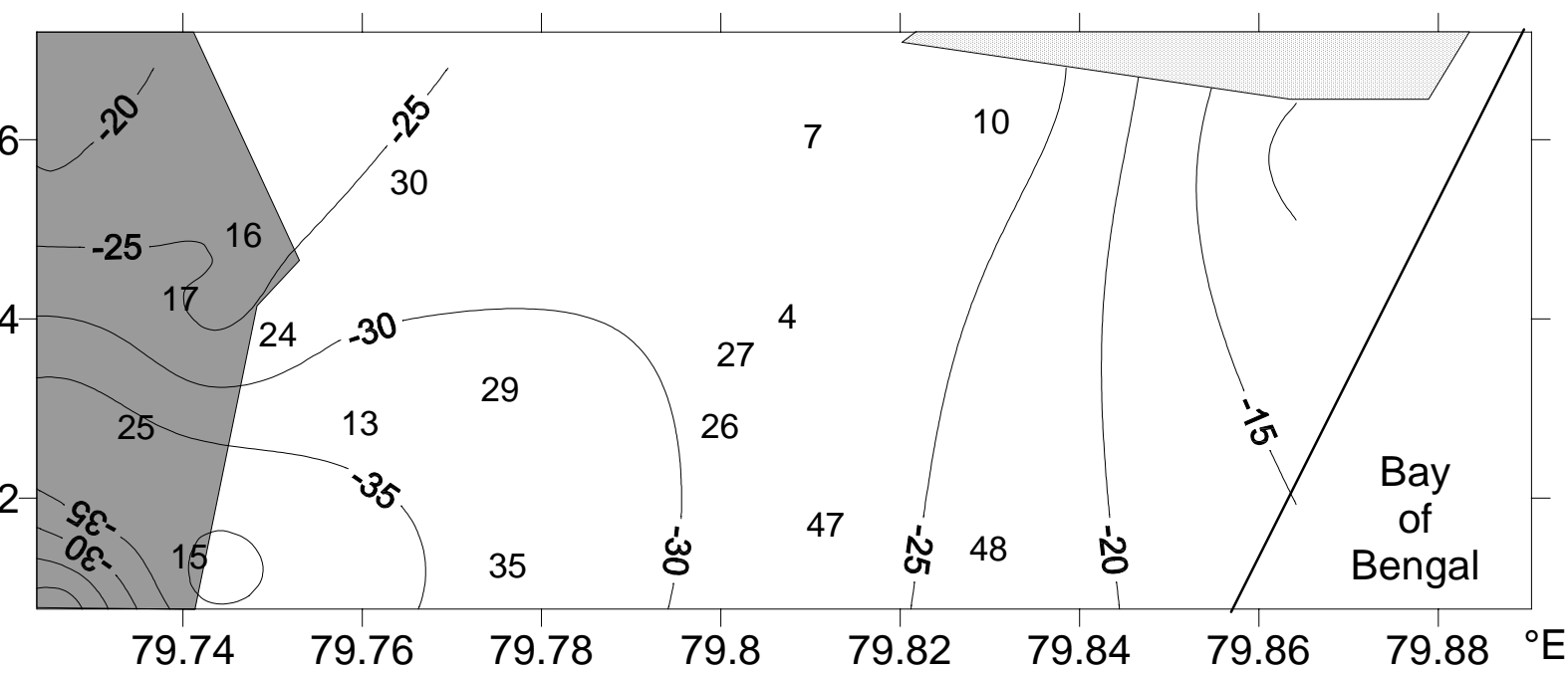

outcroping area (approximative limits)

water level $\mathrm{m}$ amsl

swamp location (no permanent water)

Figure 3 


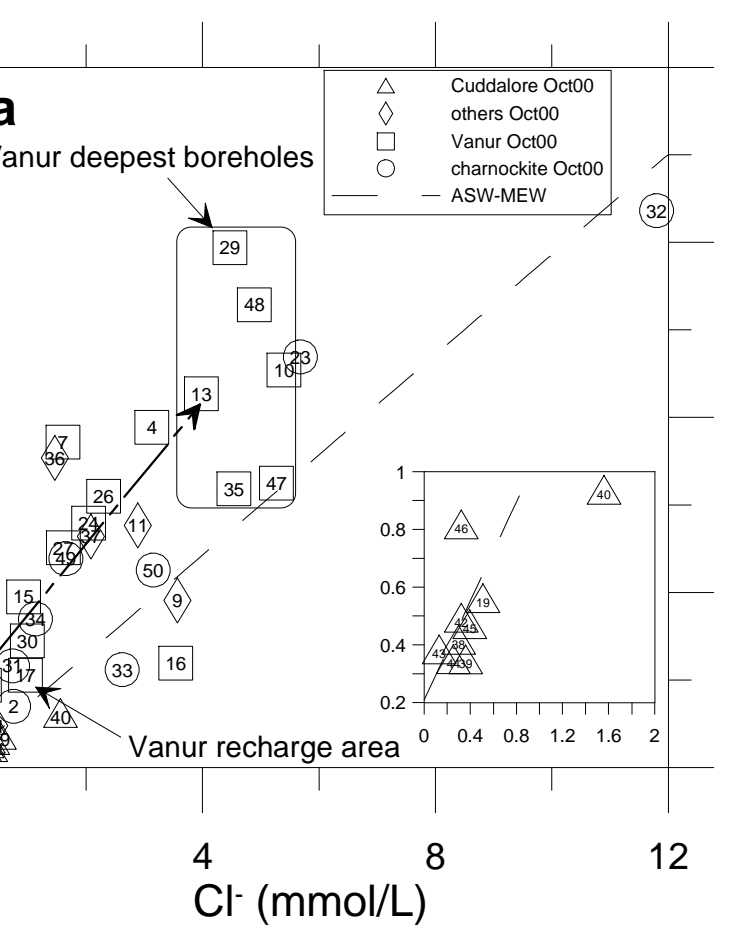

Figure 5

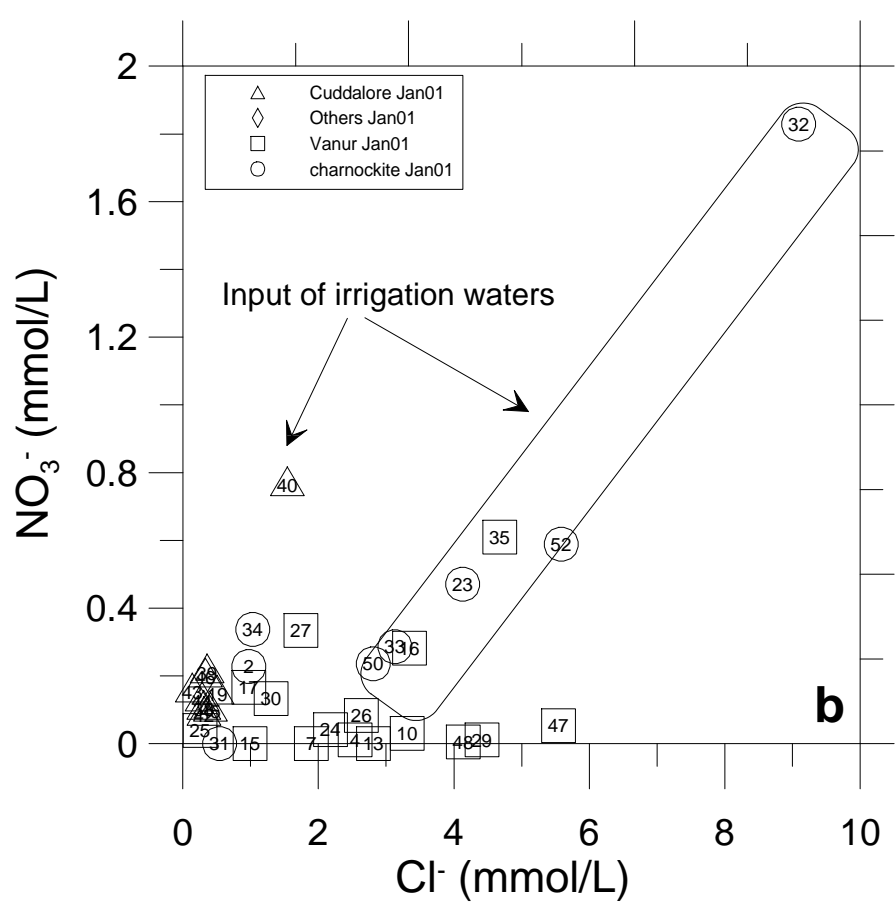




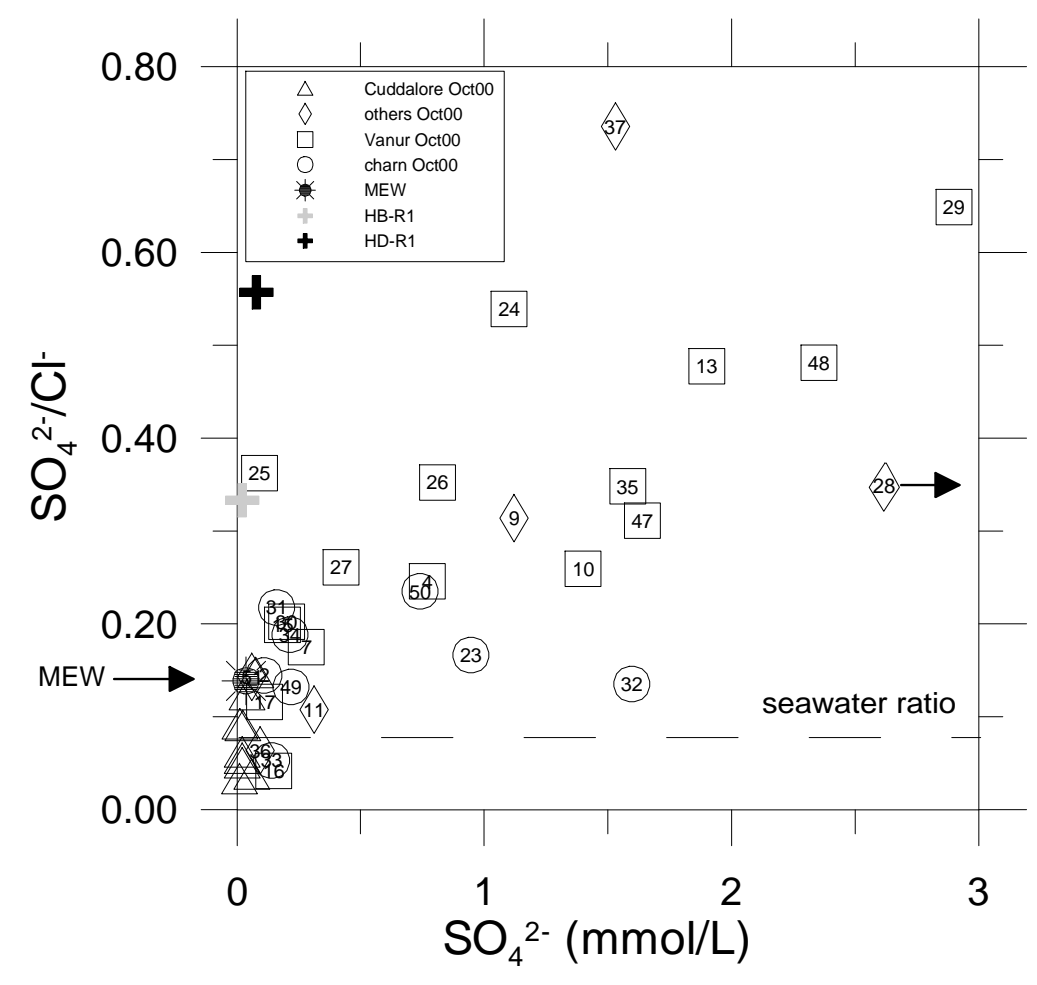

Figure 7 

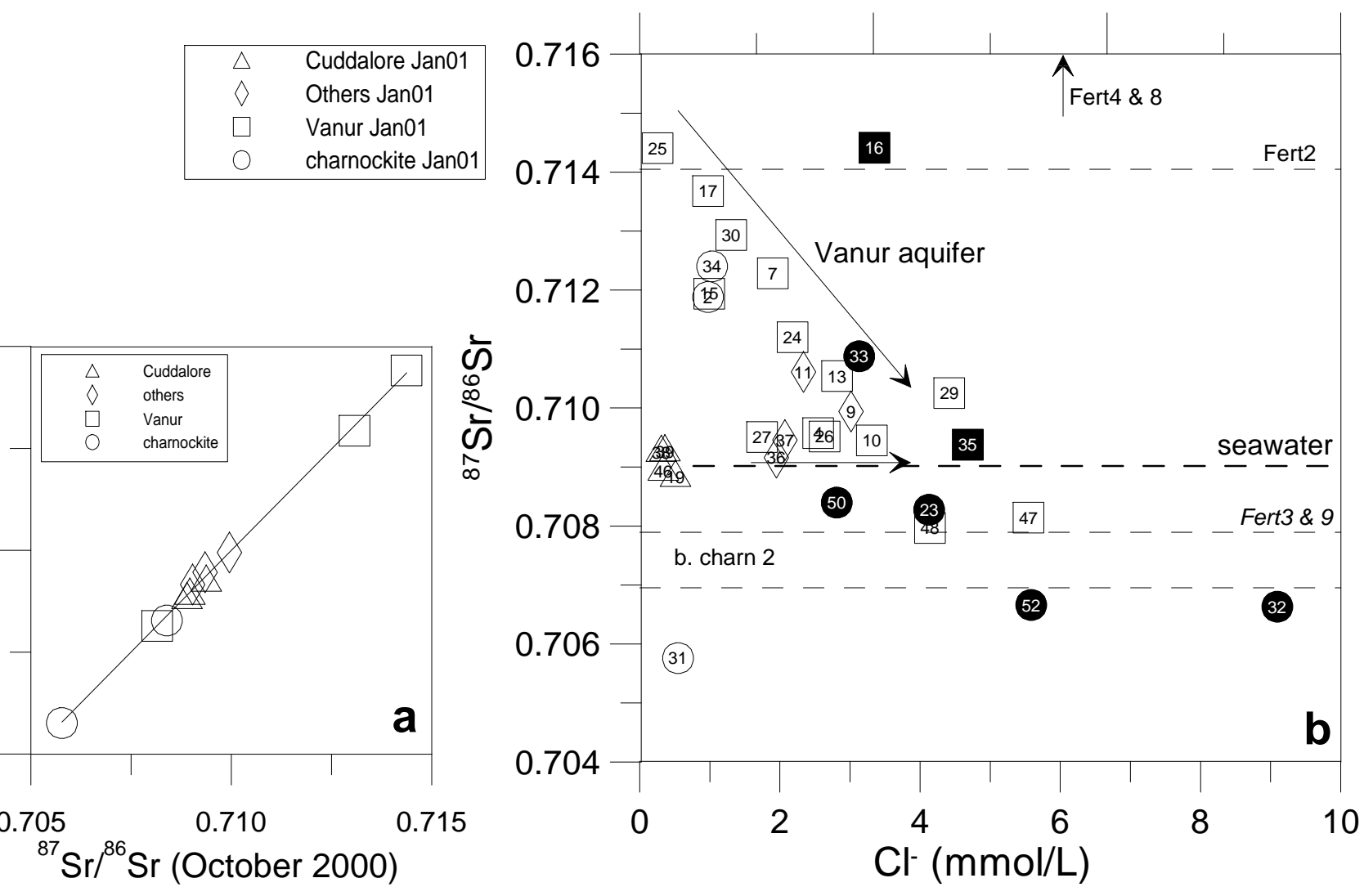

Figure 8 


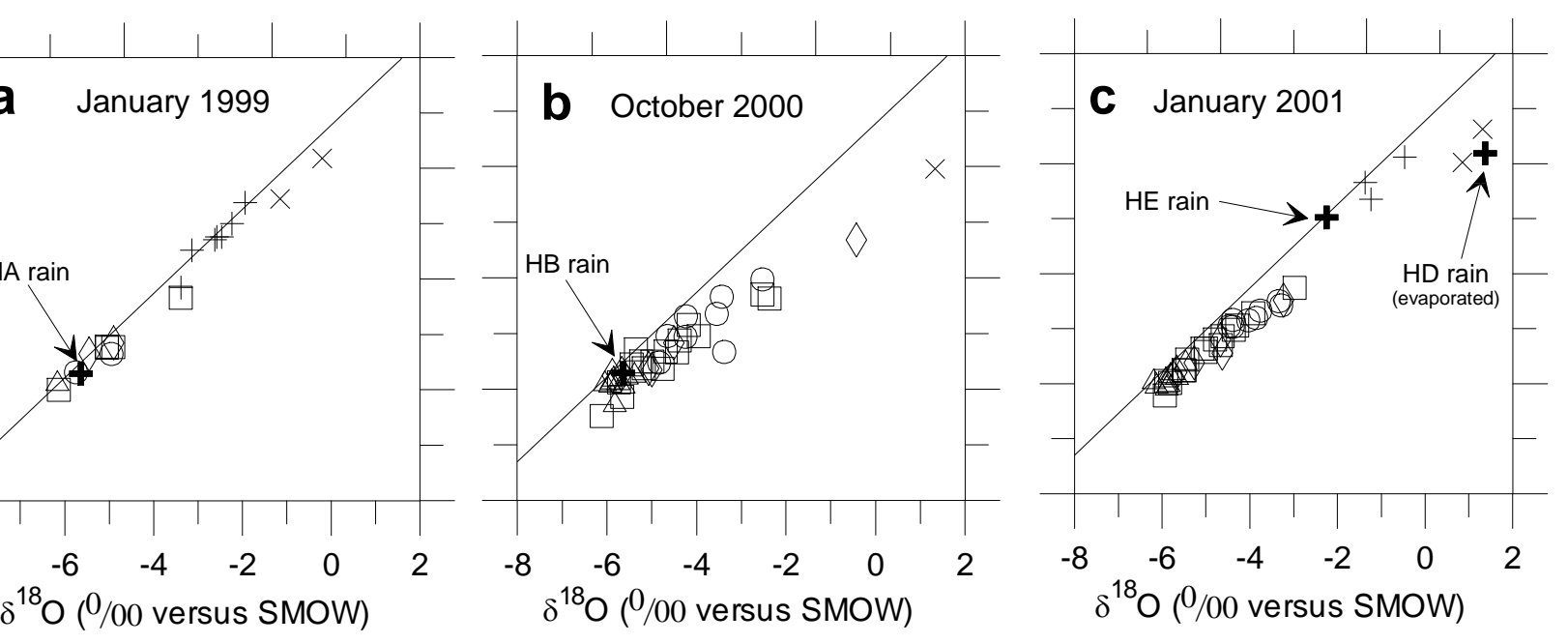

\begin{tabular}{|ll|}
\hline+ & Rain \\
+ & Ery \\
$\times$ & Swamp \\
$\triangle$ & Cuddalore \\
$\triangleright$ & Other aquifers \\
$\square$ & Vanur \\
& Charnockite \\
\hline
\end{tabular}

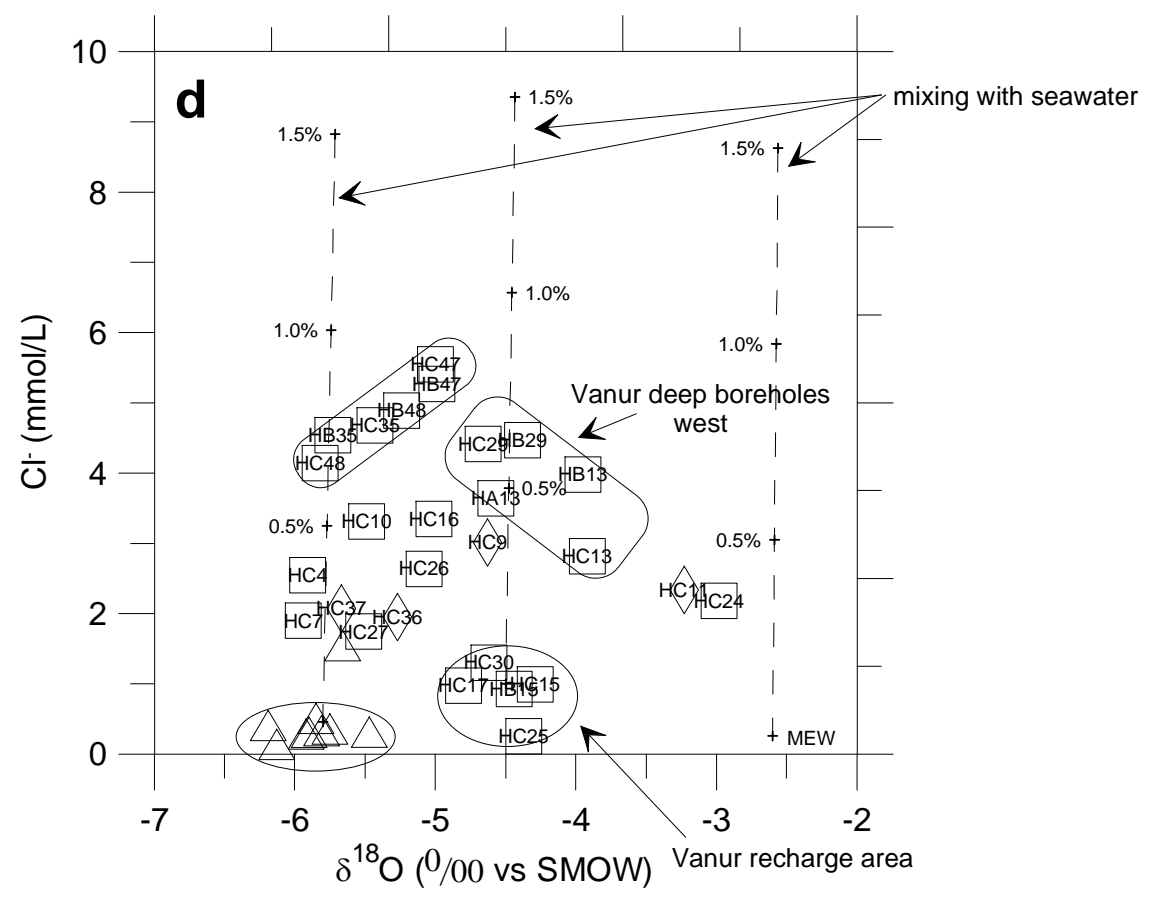

Figure 9 


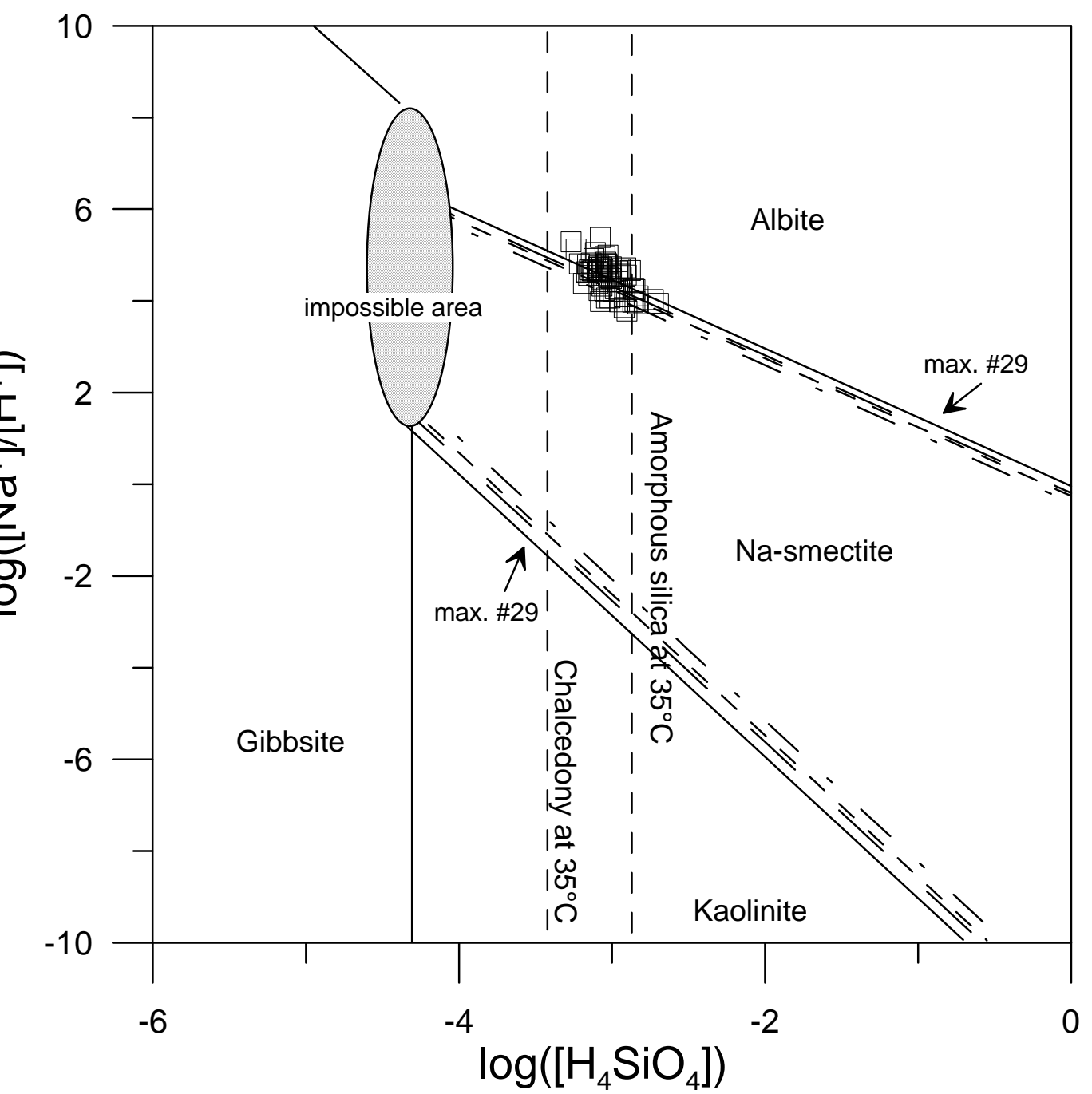

Figure 10 
Sample characteristics. bw: bore well; ow: open well; dcbw: dug cum bore well. *: located at the outcrop. Depth in m (because of a lack of t corrected by altitude).

\begin{tabular}{|c|c|c|c|c|c|c|c|c|c|}
\hline village & aquifer & $\begin{array}{c}\text { well } \\
\text { depth }\end{array}$ & $\begin{array}{l}\text { casing } \\
\text { depth }\end{array}$ & $\#$ & $\begin{array}{l}\text { water } \\
\text { body }\end{array}$ & village & aquifer & $\begin{array}{c}\text { well } \\
\text { depth }\end{array}$ & $\begin{array}{l}\text { casing } \\
\text { depth }\end{array}$ \\
\hline & & & & 27 & bw & Rayapudupakkam & $\mathrm{V}$ & 150 & 12 \\
\hline \multicolumn{2}{|l|}{ Olagapuram, sluice } & & & 28 & bw & Rayaotai & $\mathrm{O}$ & 50 & 12 \\
\hline \multicolumn{2}{|l|}{ Appirampattu, sluice } & & & 29 & bw & Turovai & $\mathrm{V}$ & 200 & 6 \\
\hline \multicolumn{2}{|l|}{ Nesal, first sluice } & & & 30 & bw & Olundiapattu & $\mathrm{V}$ & 100 & 12 \\
\hline \multicolumn{2}{|l|}{ Nesal, main sluice } & & & 31 & dcbw & Kunnam south & $\mathrm{ch}^{*}$ & & \\
\hline \multicolumn{2}{|c|}{ Vilvanatham, central sluice } & & & 32 & dcbw & Kunnam east & $\mathrm{ch}^{*}$ & & \\
\hline \multicolumn{2}{|l|}{ Pulichapallam } & & & 33 & dcbw & Parangani & ch + sed* & & \\
\hline \multicolumn{2}{|l|}{ Pulichapallam, sluice } & & & 34 & dcbw & Prammadesam & $\mathrm{ch}^{*}$ & & \\
\hline \multicolumn{2}{|l|}{ Kaluvelly, inner point } & & & 35 & bw & Rawthankuppam & $\mathrm{V}$ & 220 & \\
\hline \multirow{2}{*}{\multicolumn{2}{|c|}{ Kaluvelly, sluice gate }} & & & 36 & bw & Acharampattu & $\mathrm{T}$ & 60 & 12 \\
\hline & & & & 37 & bw & Agasampet & $\mathrm{O}$ & 33 & 6 \\
\hline Olagapuram & ch + sed* & & & 38 & bw & Utility & $\mathrm{Cd}^{*}$ & 50 & 50 \\
\hline Appirampattu & $\mathrm{V}$ & 120 & & 39 & bw & Auromodel & $\mathrm{Cd}^{*}$ & 48 & 48 \\
\hline Nesal & V & 210 & & 40 & bw & Sakti & $\mathrm{Cd}^{*}$ & 64 & 64 \\
\hline Kaluperumpakkam & $\mathrm{K}^{*}$ & 10 & & 42 & bw & Aurodam & $\mathrm{Cd}^{*}$ & 41 & 41 \\
\hline Kaluperumpakkam & $\mathrm{V}$ & 180 & & 43 & bw & Bharat Nivas & $\mathrm{Cd}^{*}$ & 40 & 40 \\
\hline Monnaiampet & $\mathrm{K}^{*}$ & 10 & & 44 & bw & Matrimandir - Banyan tree & $\mathrm{Cd}^{*}$ & 76 & 76 \\
\hline Annapurna & $\mathrm{V}$ & 180 & cased & 45 & bw & Matrimandir - Workshop & $\mathrm{Cd}^{*+\mathrm{K}}$ & 284 & 89 \\
\hline Ashram farm & $\mathrm{V}^{*}$ & 105 & 12 & 46 & bw & Silence & $\mathrm{Cd}^{*}$ & 46 & 46 \\
\hline Katrampakkam & $\mathrm{V} *$ & 95 & 12 & 47 & bw & Auroshilpam & V & 281 & 49 \\
\hline Naninarpalyam & $\mathrm{V} *$ & 75 & 12 & 48 & bw & Aurogreen & V & 391 & 299 \\
\hline Aurobrindavan & $\mathrm{Cd}^{*}$ & 171 & 12 & 49 & dcbw & Kilianoor & $\mathrm{ch}^{*}$ & 50 & \\
\hline Perimukal & $\mathrm{ch}^{*}$ & & & 50 & dcbw & Endiyur & $\mathrm{ch}^{*}$ & 20 & \\
\hline Pullichapalam & $\mathrm{V}$ & 137 & 12 & 51 & bw & Shanga & $\mathrm{K}$ & 105 & 97 \\
\hline Vanur & $\mathrm{V} *$ & 183 & 12 & 52 & dcbw & Thaludali & $\mathrm{ch}^{*}$ & & \\
\hline Rayapettai & $\mathrm{V}$ & 250 & 12 & 53 & bw & Jipmer & $\mathrm{Cd}^{*}$ & 71 & 71 \\
\hline
\end{tabular}

dalore sandstone; ch: charnockite; K: Kadaperikuppam sandstone; O: Ottai claystone; sed: sediments; T: Turuvai limestone; V: Vanur sandstone. 
$\mathrm{d}^{18} \mathrm{O}$ and dD: \%o vs SMOW.

\begin{tabular}{|c|c|c|c|c|c|c|c|c|c|c|c|c|c|}
\hline $\begin{array}{c}\mathbf{T} \\
{ }^{\circ} \mathbf{C} \\
\end{array}$ & $\begin{array}{c}\text { cond. } \\
\mu S / c m\end{array}$ & $\begin{array}{c}\text { TDS } \\
\mathrm{mg} / \mathrm{L}\end{array}$ & $\begin{array}{c}\mathrm{HCO}_{3}^{-} \\
\mathrm{mmol} / \mathrm{L}\end{array}$ & $\begin{array}{c}\mathrm{Na}^{+} \\
\mathrm{mmol} / \mathrm{L}\end{array}$ & $\begin{array}{c}\mathrm{K}^{+} \\
\mathrm{mmol} / \mathrm{L}\end{array}$ & $\begin{array}{c}\mathrm{Ca}^{2+} \\
\mathrm{mmol} / \mathrm{L}\end{array}$ & $\begin{array}{c}\mathrm{Mg}^{2+} \\
\mathrm{mmol} / \mathrm{L}\end{array}$ & $\begin{array}{c}\mathrm{H}_{4} \mathrm{SiO}_{4} \\
\mathrm{mmol} / \mathrm{L}\end{array}$ & $\begin{array}{c}\mathrm{Cl}^{-} \\
\mathrm{mmol} / \mathrm{L}\end{array}$ & $\begin{array}{c}\mathrm{SO}_{4}{ }^{2-} \\
\mathrm{mmol} / \mathrm{L}\end{array}$ & $\begin{array}{c}\mathrm{NO}_{3}^{-} \\
\mu \mathrm{mol} / \mathrm{L} \\
\end{array}$ & $\begin{array}{c}\delta^{18} \mathrm{O} \\
1 / 1000 \\
\end{array}$ & $\begin{array}{c}\delta D \\
1 / 1000 \\
\end{array}$ \\
\hline $\begin{array}{ll}28.9 & 5.51\end{array}$ & 54 & 69 & 0.32 & 0.153 & 0.078 & 0.074 & 0.058 & 0.32 & 0.18 & 0.011 & 5.8 & -0.47 & 1.22 \\
\hline $26.1 \quad 6.17$ & 105 & 111 & 0.79 & 0.556 & 0.134 & 0.234 & 0.168 & 0.20 & 0.25 & 0.037 & 0 & -1.37 & -3.44 \\
\hline 7.6 & 372 & 309 & 2.17 & 2.24 & 0.128 & 0.402 & 0.303 & 0.38 & 1.01 & 0.242 & 0 & -1.24 & -6.48 \\
\hline $26.4 \quad 7.24$ & 14400 & 9115 & 1.58 & 123 & 1.85 & 4.20 & 18.6 & 0.14 & 134 & 7.73 & n.d. & 1.31 & 6.32 \\
\hline $27.8 \quad 7.88$ & 15940 & 10203 & 2.09 & 144 & 2.55 & 3.71 & 18.9 & 0.12 & 150 & 7.72 & n.d. & 0.85 & 0.23 \\
\hline $31.7 \quad 5.45$ & 231 & 341 & 1.48 & 0.788 & 0.072 & 0.417 & 0.291 & 1.76 & 0.51 & 0.090 & 160 & -5.85 & -39.64 \\
\hline $30.3 \quad 5.39$ & 179 & 238 & 1.26 & 0.520 & 0.026 & 0.444 & 0.150 & 1.10 & 0.31 & 0.034 & 114 & -5.90 & -40.23 \\
\hline $26.5 \quad 5.57$ & 144 & 193 & 0.72 & 0.393 & 0.017 & 0.341 & 0.115 & 0.98 & 0.36 & 0.025 & 222 & -5.75 & -37.48 \\
\hline $30.3 \quad 5.34$ & 377 & 320 & 0.98 & 1.07 & 0.062 & 0.772 & 0.270 & 0.91 & 1.55 & 0.061 & 775 & -5.66 & -38.32 \\
\hline $28.2 \quad 5.22$ & 146 & 237 & 0.91 & 0.560 & 0.016 & 0.278 & 0.138 & 1.38 & 0.31 & 0.041 & 96.0 & -5.47 & -35.66 \\
\hline 5.37 & 142 & 260 & 1.05 & 0.500 & 0.022 & 0.298 & 0.112 & 1.58 & 0.14 & 0.025 & 165 & -6.13 & -39.91 \\
\hline $29.5 \quad 5.78$ & 217 & 286 & 1.66 & 0.463 & 0.042 & 0.625 & 0.210 & 1.24 & 0.29 & 0.043 & 139 & -5.92 & -38.76 \\
\hline 5.82 & 257 & 338 & 2.01 & 0.535 & 0.045 & 0.719 & 0.240 & 1.48 & 0.41 & 0.033 & 109 & -6.19 & -39.07 \\
\hline $28.8 \quad 5.84$ & 287 & 398 & 2.40 & 0.895 & 0.028 & 0.611 & 0.360 & 1.74 & 0.34 & 0.051 & 210 & -5.81 & -37.99 \\
\hline 6.83 & 1188 & 1073 & 7.75 & 3.42 & 0.013 & 2.23 & 2.54 & 1.47 & 3.01 & 1.18 & 138 & -4.63 & -34.43 \\
\hline $27.8 \quad 7.71$ & 786 & 693 & 5.39 & 3.03 & 0.032 & 1.08 & 1.68 & 1.02 & 2.34 & 0.260 & 33.0 & -3.23 & -24.80 \\
\hline 6.76 & 1034 & 986 & 8.63 & 5.36 & 0.040 & 1.28 & 1.60 & 1.44 & 1.95 & 0.141 & 387 & -5.27 & -36.21 \\
\hline 6.77 & 6830 & 5085 & 10.60 & 43.5 & 0.700 & 5.48 & 13.0 & 1.24 & 40.1 & 13.9 & n.d. & -4.67 & -32.03 \\
\hline 6.34 & 1142 & 1025 & 7.27 & 3.46 & 0.014 & 3.91 & 0.550 & 1.15 & 2.07 & 1.42 & 190 & -5.67 & -37.90 \\
\hline 6.69 & 1173 & 1051 & 8.59 & 6.67 & 0.113 & 1.45 & 2.02 & 0.95 & 2.55 & 0.837 & 11.2 & -5.91 & -39.48 \\
\hline 7.56 & 1126 & 1046 & 9.61 & 6.68 & 0.115 & 1.50 & 1.84 & 0.84 & 1.90 & 0.500 & 0 & -5.94 & -42.14 \\
\hline 6.89 & 1292 & 1097 & 8.47 & 7.02 & 0.113 & 1.75 & 1.98 & 0.81 & 3.31 & 1.03 & 30.0 & -5.49 & -37.56 \\
\hline 30.6 & 1266 & 1099 & 7.59 & 7.02 & 0.126 & 1.47 & 2.23 & 0.91 & 2.82 & 1.76 & 0 & -3.92 & -27.20 \\
\hline $29.5 \quad 7.05$ & 772 & 721 & 7.10 & 3.64 & 0.071 & 1.08 & 1.61 & 0.68 & 0.99 & 0.190 & 0 & -4.29 & -29.43 \\
\hline 6.69 & 1020 & 889 & 6.82 & 1.99 & 0.127 & 2.07 & 2.22 & 1.41 & 3.35 & 0.147 & 282 & -5.01 & -34.25 \\
\hline 6.7 & 655 & 739 & 6.85 & 1.43 & 0.141 & 1.61 & 1.93 & 1.20 & 0.97 & 0.115 & 166 & -4.80 & -31.93 \\
\hline 7.08 & 1094 & 949 & 7.56 & 4.46 & 0.085 & 1.40 & 2.39 & 0.82 & 2.18 & 1.14 & 41.0 & -2.98 & -22.57 \\
\hline 6.82 & 609 & 613 & 6.24 & 1.74 & 0.104 & 1.22 & 1.36 & 0.92 & 0.26 & 0.070 & 38.3 & -4.37 & -30.18 \\
\hline $30.2 \quad 6.85$ & 1205 & 1032 & 7.53 & 6.45 & 0.077 & 2.08 & 1.37 & 0.74 & 2.64 & 1.41 & 83.0 & -5.08 & -33.67 \\
\hline $28.8 \quad 6.57$ & 868 & 803 & 6.78 & 2.56 & 0.050 & 2.07 & 1.30 & 1.12 & 1.74 & 0.250 & 334 & -5.51 & -37.55 \\
\hline $30.3 \quad 6.93$ & 1722 & 1442 & 9.77 & 9.90 & 0.128 & 1.57 & 3.60 & 0.76 & 4.42 & 2.42 & 11.0 & -4.66 & -33.00 \\
\hline $29.1 \quad 6.82$ & 813 & 750 & 7.21 & 2.56 & 0.064 & 1.19 & 2.10 & 0.82 & 1.30 & 0.176 & 133 & -4.62 & -31.36 \\
\hline 6.57 & 1444 & 1171 & 6.80 & 4.53 & 0.048 & 4.10 & 1.30 & 0.90 & 4.68 & 1.71 & 610 & -5.43 & -35.60 \\
\hline 7.06 & 1431 & 1101 & 5.93 & 5.46 & 0.162 & 2.46 & 2.10 & 0.93 & 5.55 & 1.75 & 53.3 & -5.00 & -33.61 \\
\hline $31.7 \quad 6.94$ & 1267 & 976 & 4.94 & 7.20 & 0.127 & 1.74 & 1.33 & 0.69 & 4.14 & 1.97 & 4.50 & -5.82 & -39.86 \\
\hline 7.51 & 572 & 579 & 4.49 & 1.44 & 0.019 & 1.71 & 0.459 & 1.38 & 0.97 & 0.105 & 228 & -4.04 & -28.48 \\
\hline $29.2 \quad 6.97$ & 1403 & 1250 & 8.01 & 7.71 & 2.89 & 1.04 & 1.02 & 1.68 & 4.13 & 0.700 & 470 & -4.39 & -28.41 \\
\hline $26.7 \quad 7.16$ & 637 & 598 & 6.15 & 2.22 & 0.010 & 1.46 & 1.06 & 0.58 & 0.55 & 0.123 & 0 & -3.76 & -26.72 \\
\hline 7.53 & 1954 & 1439 & 7.04 & 7.90 & 0.049 & 3.89 & 2.30 & 0.64 & 9.09 & 1.22 & 1830 & -4.47 & -29.57 \\
\hline $30.9 \quad 6.82$ & 812 & 701 & 4.98 & 1.82 & 0.027 & 1.66 & 1.80 & 1.04 & 3.13 & 0.166 & 287 & -3.29 & -25.77 \\
\hline $27.3 \quad 7.24$ & 697 & 712 & 5.55 & 2.56 & 0.037 & 1.79 & 0.590 & 1.56 & 1.03 & 0.200 & 337 & -4.39 & -29.65 \\
\hline $27.3 \quad 7.14$ & 1130 & 970 & 7.75 & 3.90 & 0.098 & 2.28 & 1.92 & 0.94 & 2.81 & 0.630 & 236 & -3.34 & -25.01 \\
\hline $27.3 \quad 7.29$ & 1273 & 1010 & 5.61 & 4.33 & 0.022 & 2.56 & 1.62 & 1.40 & 5.59 & 0.580 & 588 & -3.86 & -28.03 \\
\hline & & & & & 0.003 & & & 0.06 & 0.14 & 0.078 & 0 & 1.37 & 1.89 \\
\hline $29.8 \quad 7.67$ & 65300 & & 2.32 & 710 & 16.2 & 16.20 & 77.5 & 0.13 & & & & & \\
\hline $30.7 \quad 5.61$ & 243 & 311 & 1.52 & 0.754 & 0.069 & 0.452 & 0.313 & 1.42 & 0.51 & 0.080 & 166 & & \\
\hline $29.9 \quad 5.84$ & 193 & 201 & 0.66 & 0.551 & 0.032 & 0.480 & 0.179 & 1.04 & 0.30 & 0.043 & 120 & & \\
\hline 5.13 & 128 & 183 & 0.63 & 0.400 & 0.016 & 0.308 & 0.117 & 0.98 & 0.30 & 0.036 & 191 & & \\
\hline $32.4 \quad 5.91$ & 425 & 374 & 0.97 & 1.37 & 0.091 & 0.989 & 0.331 & 1.13 & 1.88 & 0.082 & 792 & & \\
\hline 30.8 & 164 & 212 & 1.04 & 0.572 & 0.020 & 0.341 & 0.180 & 1.22 & & & & & \\
\hline $30.9 \quad 7.13$ & 143 & 262 & 1.01 & 0.508 & 0.013 & 0.320 & 0.140 & 1.61 & 0.15 & 0.032 & 146 & & \\
\hline $31.6 \quad 6.33$ & 427 & 456 & 3.70 & 0.743 & 0.052 & 1.49 & 0.430 & 1.17 & 0.37 & 0.049 & 180 & & \\
\hline 6.05 & 346 & 404 & 2.90 & 0.588 & 0.048 & 1.21 & 0.358 & 1.34 & 0.40 & 0.041 & 128 & & \\
\hline $29.2 \quad 6.24$ & 312 & 417 & 2.47 & 0.972 & 0.031 & 0.795 & 0.365 & 1.80 & 0.33 & 0.064 & 180 & & \\
\hline $31.1 \quad 6.68$ & 457 & 481 & 3.91 & 1.00 & 0.046 & 1.51 & 0.458 & 1.18 & 0.41 & 0.102 & 132 & -6.18 & -40.29 \\
\hline 6.9 & 1210 & 1103 & 7.59 & 3.44 & 0.018 & 2.56 & 2.96 & 1.35 & 3.49 & 1.25 & 160 & & \\
\hline $30.9 \quad 7.74$ & 680 & 723 & 4.50 & 4.25 & 0.046 & 0.838 & 1.80 & 0.91 & 3.91 & 0.472 & 0 & & \\
\hline $30.5 \quad 7.05$ & 1309 & 1091 & 8.41 & 7.40 & 0.101 & 1.44 & 1.95 & 1.03 & 4.00 & 0.407 & 310 & & \\
\hline 6.67 & 4260 & 3065 & 7.93 & 20.5 & 0.093 & 4.66 & 9.57 & 1.36 & 26.20 & 6.54 & n.d. & & \\
\hline $30.2 \quad 7.01$ & 1075 & 1039 & 7.45 & 3.94 & 0.017 & 3.64 & 0.65 & 1.15 & 1.72 & 1.57 & 153 & & \\
\hline $31.9 \quad 6.59$ & 1143 & 1050 & 8.99 & 6.24 & 0.113 & 1.65 & 2.24 & 0.81 & 2.37 & 0.744 & 0 & & \\
\hline $31.8 \quad 6.76$ & 1094 & 1017 & 9.50 & 6.27 & 0.115 & 1.66 & 1.97 & 0.70 & 1.76 & 0.410 & 0 & & \\
\hline $30.7 \quad 6.73$ & 1500 & 1172 & 6.47 & 8.10 & 0.080 & 1.80 & 2.51 & 0.80 & 5.56 & 1.76 & 160 & & \\
\hline $30.7 \quad 6.96$ & 1260 & 1121 & 7.42 & 7.40 & 0.126 & 1.63 & 2.48 & 0.73 & 2.85 & 2.04 & 0 & & \\
\hline $30.9 \quad 7.01$ & 747 & 694 & 6.55 & 4.24 & 0.061 & 0.922 & 1.47 & 0.68 & 0.94 & 0.240 & 0 & & \\
\hline $29.9 \quad 6.91$ & 1035 & 879 & 6.75 & 1.92 & 0.122 & 2.35 & 2.50 & 1.12 & 3.68 & 0.165 & 147 & & \\
\hline $28.9 \quad 6.96$ & 695 & 663 & 6.16 & 1.27 & 0.138 & 1.58 & 1.94 & 0.97 & 0.84 & 0.130 & 103 & & \\
\hline $30.5 \quad 7.04$ & 553 & 587 & 5.48 & 1.63 & 0.084 & 1.41 & 1.10 & 1.12 & 0.21 & 0.100 & 63 & & \\
\hline 6.61 & 1038 & 961 & 9.01 & 5.95 & 0.092 & 1.48 & 1.65 & 0.65 & 1.68 & 0.488 & 48 & & \\
\hline $29.8 \quad 6.58$ & 882 & 876 & 7.08 & 3.38 & 0.062 & 2.01 & 1.44 & 1.48 & 1.99 & 0.243 & 210 & & \\
\hline 6.66 & 1700 & 1419 & 9.27 & 9.30 & 0.124 & 1.92 & 3.32 & 0.72 & 4.50 & 2.59 & 0 & & \\
\hline 6.79 & 735 & 695 & 6.43 & 2.64 & 0.064 & 1.22 & 1.97 & 0.90 & 0.91 & 0.183 & 111 & & \\
\hline
\end{tabular}


ble 4. Chemical composition and ${ }^{87} \mathrm{Sr} /{ }^{86} \mathrm{Sr}$ ratio of typical fertilizer used in this area. MOP: muriate of potash; AP: di-ammonium phosphate $(4: 2: 18)(\mathrm{N}: \mathrm{P}: \mathrm{K})$.

\begin{tabular}{llll} 
abel & Trade mark and company & Measured composition (in weight) & ${ }^{87} \mathbf{S r}{ }^{86} \mathbf{S r}$ \\
\hline & & & \\
$\mathrm{rt} 2$ & MOP - Indian Potash Limited & $\mathrm{K}^{+} 52 \%-\mathrm{Cl}^{-} 48 \%$ & 0.714050 \\
$\mathrm{rt} 3$ & DAP - SPIC Limited & $\mathrm{NO}_{3}^{-} 37 \%-\mathrm{SO}_{4}{ }^{2-} 10 \%-53 \%$ other & 0.707896 \\
$\mathrm{rt} 4$ & $\begin{array}{l}\text { Complex fertiliser 17:17:17 - } \\
\text { Madras Fertiliser Ltd, Chennai }\end{array}$ & $\mathrm{K}^{+} 15 \%-\mathrm{Cl}^{-} 14 \%-\mathrm{NO}_{3}{ }^{-} 17 \%-54 \%$ & 0.718762 \\
$\mathrm{other}$ & \\
$\mathrm{rt} 8$ & MOP - SPIC Ltd, Tuticorun & $\mathrm{K}^{+} 52 \%-\mathrm{Cl}^{-} 48 \%$ & 0.722003 \\
$\mathrm{rt} 9$ & $\begin{array}{l}\text { Superphosphate - EID Parry } \\
\text { Ltd, Chennai }\end{array}$ & $\mathrm{Ca}^{2+} 13 \%-\mathrm{NO}_{3}^{-} 14 \%-\mathrm{SO}_{4}{ }^{2-} 32 \%-$ & 0.707838 \\
& & $61 \%$ other & \\
\hline
\end{tabular}




\begin{tabular}{|c|c|c|c|c|c|c|c|}
\hline & quartz & $\begin{array}{c}\text { micro- } \\
\text { perthite }\end{array}$ & plagioclase & pyroxene & amphibole & biotite & $\begin{array}{c}\text { muscovite/ } \\
\text { sericite } \\
\end{array}$ \\
\hline charnockite & $27+/-4$ & $51+/-8$ & $13+/-4$ & $3+/-1$ & 1 & $3+/-1$ & trace \\
\hline \multirow[t]{2}{*}{ harnockite } & $18+/-2$ & $69+/-5$ & $3+/-2$ & 0 & 0 & $10+/-5$ & 0 \\
\hline & $\begin{array}{c}\text { muscovite/ } \\
\text { sericite } \\
\end{array}$ & $\begin{array}{c}\text { Fe-oxides, } \\
\mathrm{TiO}_{2} \\
\end{array}$ & apatite & & Sample & ${ }^{87} \mathrm{Sr} /{ }^{86} \mathrm{Sr}$ & $2 \sigma$ \\
\hline \multirow[t]{2}{*}{ charnockite } & traces & $2+/-1$ & trace & & black charn.1 & 0.721869 & 0.000006 \\
\hline & & & & & black charn.2 & 0.706954 & 0.000007 \\
\hline harnockite & 0 & 0 & 0 & & pink charn. & 0.727856 & 0.000007 \\
\hline
\end{tabular}

